A RCHIWA, BIBLIOTEKI

I MUZEA KOŚCIELNE 109 (2018)

https://doi.org/10.31743/abmk.2018.109.04

GRZEGORZ CHAJKO* - KRAKÓW

\title{
RELACJE NIEMIECKO-POLSKIE \\ W RZYMSKOKATOLICKIEJ PARAFII PW. ŚWIĘTEJ TRÓJCY \\ W MACHLIŃCU W ARCHIDIECEZJI LWOWSKIEJ OBRZĄDKU \\ LACIŃSKIEGO W PRZEKAZIE KS. WLADYSLAWA KRZYSTYNIAKA Z 1922 ROKU
}

W dobie obecnych badań naukowych, dotyczących historii Kresów Południowo-Wschodnich II Rzeczypospolitej, bardzo wiele miejsca i uwagi poświęca się relacjom między społecznością polską a ukraińską, zamieszkującą te tereny, opisuje ich zwyczaje, dotykając przy okazji kwestii wzajemnych antagonizmów, których eskalacja nastąpiła w okresie drugiej wojny światowej ${ }^{1}$. Trudno się dziwić takiemu zainteresowaniu badaczy, gdyż obie te społeczności stanowiły największe grupy narodowościowe. Ważnym jednak czynnikiem decydującym o takim zainteresowaniu jest fakt, że zachowało się bardzo dużo różnych materiałów źródłowych oraz wielu żyjących jeszcze świadków i uczestników wydarzeń, co pozwala na podejmowanie głębokich i daleko idących analiz.

W sferze badań relacji tych dwóch społeczności z innymi narodowościami, które również zamieszkiwały Małopolskę Wschodnią, takimi jak np. Żydzi, Niemcy, Czesi, Ormianie, brak jest dostatecznych opracowań. Niedostatek w tym względzie może wynikać chociażby z braku większej bazy źródłowej, a także konieczności wnikliwych i szczegółowych eksploracji archiwów. W tym przypadku ów drugi aspekt wydaje się być tutaj decydującym, gdyż, jak wolno przypuszczać, wszelkie opracowania takich relacji wymagają sięgnięcia w życie społeczności

* Grzegorz Chajko - dr historii; adiunkt w Instytucie Historii Uniwersytetu Papieskiego Jana Pawła II w Krakowie; e-mail: grzegorz.chajko@upjp2.edu.pl

${ }^{1}$ Zob. R. Torzecki, Kwestia ukraińska w Polsce w latach 1923-1929, Kraków 1989; tenże, Polacy i Ukraincy. Sprawa ukrainska w czasie II wojny światowej na terenie II Rzeczypospolitej, Warszawa 1993; W. Poliszczuk, Zginęli z rąk ukraińskich, Toronto 1998; tenże, Posłanie do braci Polaków. Prawosławnego Ukraińca w 55-ta rocznicę mordów wołyńskich, Toronto-Warszawa 1998; tenże, Ukraińskie ofiary OUN-UPA, Toronto 1998; Eksterminacja narodu polskiego i Kościota rzymskokatolickiego przez ukraińskich nacjonalistów w Matopolsce Wschodniej w latach 19391945. Materiały źródłowe, oprac. J. Wołczański, cz. 1, Kraków 2005; cz. 2. Kraków 2006. 
lokalnych, zamieszkujących małe miasteczka i wsie, a to zaś powoduje spore trudności.

Opisywane realia dotyczą w dużej mierze również społeczności niemieckiej, która od czasów kolonizacji józefińskiej - w latach 80. XVIII w. i późniejszej - z 1. połowy XIX w., zamieszkiwała kilkadziesiąt miejscowości ówczesnej austriackiej Galicji Wschodniej. Fakty związane z zasiedlaniem omawianych terenów, były wielokrotnie już w historiografii omawiane i poruszane, ale analiza ta nie wychodzi zasadniczo poza 1. połowę XIX w.

Wśród miejscowości zamieszkiwanych przez Niemców znalazł się także Machliniec - wieś w powiecie stryjskim, w województwie stanisławowskim. Jej początki sięgają 1823 r., kiedy to została ona założona jako kolonia dla nowo przybyłych z Czech osadników niemieckich, wyznania rzymskokatolickiego. Sprowadzili ich na tereny swojego majątku dwaj Polacy: Feliks i Stanisław Dobrzańscy - właściciele Daszawy². Pod względem przynależności parafialnej miejscowość początkowo należała do parafii w Kochawinie, ale dzięki aktywnym zabiegom czynionym przez kolonistów, została w 1842 r. utworzona w Machlińcu ekspozytura. Dopiero w dniu 24 stycznia 1909 r. austrowęgierskie Ministerstwo Wyznań i Oświaty wydało decyzję o utworzeniu parafii w Machlińcu, lecz z niewiadomych przyczyn nowy status wprowadzono dopiero od 1926 r., kiedy to zmiane odnotowano w urzędowych schematyzmach archidiecezjalnych ${ }^{3}$.

Wierni parafii Machliniec nie pozostali również obojętni wobec kwestii własnej świątyni. W 1838 r. wystąpili oni do władz kościelnych i świeckich o budowę kaplicy, którą niedługo potem, drewnianą, poświęcił w 1842 r. ks. Sebastian Iwański. Swiątynię tę traktowali oni jednak jako tymczasową o czym świadczy fakt, iż już w 1858 r. podjęto myśl o budowie murowanego kościoła ze składek wiernych. Tempo budowy, jak na ówczesne warunki, było dość duże, stąd też już w 1862 r. został on poświęcony, a w dniu 9 czerwca 1868 r. konsekrowany przez arcybiskupa lwowskiego Franciszka Ksawerego Wierzchleyskiego. Kościół otrzymał wezwanie Świętej Trójcy ${ }^{4}$.

Pod koniec 1939 r. osadnicy niemieccy wyjechali z Machlińca oraz z sąsiednich miejscowości i przenieśli się w okolice miasta Paderborn (Rzesza Niemiecka). W 1942 r. świątynię przejęli wierni obrządku greckokatolickiego, wykorzystując ją jako cerkiew do ok. 1960 r. Potem obiekt, na polecenie władz sowieckich, zamknięto i opustoszały ulegał znacznej destrukcji. Od 1995 r., przebudowany w stylu cerkiewnym, służy nadal grekokatolikom ${ }^{5}$.

W okresie II Rzeczypospolitej, podobnie jak w XIX w., parafia Machliniec należała do archidiecezji lwowskiej, a pod względem administracji dekanalnej,

${ }^{2}$ Daszawa - wieś i gmina w pow. Stryj, woj. stanisławowskie.

${ }^{3}$ P. Krasny, Kościót parafialny p.w. Świętej Trójcy w Machlińcu, w: Kościoły i klasztory rzymskokatolickie dawnego województwa ruskiego, t. 9, red. J. K. Ostrowski, Kraków 2001, s. 95 [drobne nieścisłości]; Machliniec, w: Stownik geograficzny Królestwa Polskiego i innych krajów słowiańskich, red. F. Sulimierski, B. Chlebowski, W. Walewski, t. 5, Warszawa 1884, s. 873.

${ }^{4}$ Krasny, Kościót parafialny p.w. Świętej Trójcy w Machlińcu, s. 95-96.

${ }^{5}$ Tamże, s. 96. 
do dekanatu stryjskiego. Zamieszkiwało ją wg stanu z 1921 r. -1.838 parafian, z których tylko 208 było Polakami.

Parafia składała się z sześciu wsi i osad: Machliniec, Izydorówka, Kontrowers, Kornelówka, Nowe Sioło i Wola Obłaźnicka, jednakże w żadnej Polacy nie stanowili większości, a w Kontrowersie nie było żadnego ${ }^{6}$.

Przedstawiony powyżej stan narodowościowy parafii odbiegał diametralnie od innych, licznie rozsianych parafii na terenie archidiecezji lwowskiej, gdzie niemal wszędzie wierni obrządku rzymskokatolickiego rekrutowali się spośród Polaków. Dominacja niemiecka w parafii machlinieckiej - co wykazuje w edytowanym poniżej dokumencie jego autor ks. Władysław Krzystyniak - zdecydowanie wpływała na poczucie ich świadomości narodowej, umacniała w przekonaniu o słuszności własnych wartości i determinowała w ich obronie. Stąd też nie dopuszczali oni w żaden sposób do swojego życia codziennego, zawodowego, a nawet religijnego jakichkolwiek aspektów związanych z językiem polskim, a nawet liturgią po polsku. Ten stan rzeczy, zastany przez nowo przybyłego do Machlińca ekspozyta ks. W. Krzystyniaka, zmusił do przedstawienia istniejącej sytuacji, w powierzonym mu Kościele lokalnym, swym przełożonym w Kurii Metropolitalnej we Lwowie, z licznymi sugestiami dotyczącymi zrównania w prawach i liturgii kościelnej wiernych obu narodowości.

Ks. W. Krzystyniak starał się zająć w omawianym dokumencie rolę obiektywnego obserwatora lokalnych relacji, starając się zrozumieć racje obu stron. Swoje wystąpienie podzielił on na kilka rozdziałów, chcąc zapewne w ten sposób przystępnie przedstawić najważniejsze dane. $Z$ tego też zapewne powodu zdecydował się on najpierw na ujęcie kwestii podstawowych, takich jak statystyka ogólna, oraz charakterystykę parafian pod względem narodowym i religijnym, zwracając przy tym uwagę na ich wzajemne relacje. W dalszej części zwrócił on uwagę Kurii na stan kościoła parafialnego, kaplic filialnych oraz różnopłaszczyznowym podejściu, na szeroko rozumianym gruncie kościelnym, wiernych do duszpasterza. Co ważne, ks. W. Krzystyniak omawiał także sprawy materialne w tym aspekcie, ale priorytetem stały się dla niego potrzeby duchowe i sposób ich jak najlepszego zapewnienia. Jedną trzecią swojego sprawozdania poświęcił sytuacji ludności polskiej, która w jego opisie i mniemaniu przedstawia się jako mniejszość pozbawiona jakichkolwiek praw do języka polskiego w kościele.

W omawianym sprawozdaniu ks. W. Krzystyniak poruszał również kilkukrotnie, problemy związane z budownictwem sakralnym, a zwłaszcza, z kwestiami związanymi z budową kaplic filialnych w Nowym Siole i Krechówce. Informacje przez niego podane są unikatowe, gdyż nie dość, że opisują okoliczności ich powstania, to także uzupełniają współczesną wiedzę na temat ich architektury i etapów powstawania. Jest to tym ważniejsze, że nawet współczesne opracowania dotyczące tegoż zagadnienia nic o nich nie wspominają ${ }^{7}$ Pozostałe zresztą aspekty życia społeczności niemiecko-polskiej parafii w Machlińcu również nie

\footnotetext{
${ }^{6}$ Dane przytoczone na podstawie edytowanego dokumentu.

${ }^{7}$ Krasny, Kościót parafialny p.w. Świętej Trójcy w Machlińcu, s. 95-99.
} 
znajdują swojego odzwierciedlenia w żadnej literaturze. Trudno też by było zapewne znaleźć takie kompendium wiedzy w źródłach archiwalnych.

Kilka zdań uwagi należy się również osobie samego autora sprawozdania ks. Władysławowi Krzystyniakowi ${ }^{8}$, który obejmując posadę ekspozyta w Machlińcu miał zaledwie 30 lat. W historii swojej pracy duszpasterskiej, jak świadczy chociażby dołączony biogram, należał do szerokiej rzeszy kapłanów archidiecezji lwowskiej, pracujących na niwie parafialnej. Widać jednak na podstawie napisanych przez niego słów, że przynajmniej w Machlińcu, okazał się światłym i przedsiębiorczym duszpasterzem, oddanym powierzonej mu społeczności. Starał się też, jako Polak, zapewnić dostateczną opiekę duszpasterską swoim rodakom zamieszkującym Machliniec, jednakże w tym działaniu nadrzędną wartością był dla niego Kościół rzymskokatolicki. Pragnął, aby zarówno Niemcy jak i Polacy posiadali równy do niego dostęp. Warto też podkreślić, że sporządzony przez duchownego dokument nie został w lwowskiej Kurii zlekceważony, ale wolno przypuszczać, że stał się on kluczem do rozwiązania problemu granic miejscowej parafii ${ }^{9}$. Nie znamy niestety dalszej ścieżki realizacji postulatów młodego duchownego przez Kurię, ale faktem pozostaje, że newralgiczną Krechówkę włączono w okresie międzywojennym do Machlińca ${ }^{10}$.

Edytowane sprawozdanie nie doczekało się, jak dotąd, szerszego wykorzystania w literaturze dotyczącej Kresów i relacji międzynarodowych na terenie Małopolski Wschodniej, poza jedną publikacją popularnonaukową, która przybliżała relacje polsko-niemieckie na podstawie omawianego dokumentu ${ }^{11}$. Pozostaje zatem żywić nadzieję, że kompletne wydanie tekstu stanie się przyczynkiem do dalszych badań i analiz.

W oryginale ks. Władysław Krzystyniak zastosował tytuł: Sprawozdanie z parafii rz. kat. Machliniec dziekanatu Stryj dla Najprzewielebniejszej Kurii Metropolitalnej obrz. łac. we Lwowie z roku 1921/1922, który jednak zdecydowano się pozostawić jedynie jako tytuł w części edytowanej, a artykuł oznaczyć innym,

${ }^{8}$ Władysław Krzystyniak (1891-1973) - święcenia kapłańskie w 1919 r. we Lwowie, wikariusz par. Grzymałów 1919-1921, administrator par. Touste 1921, ekspozyt w Machlińcu 1921-1924, proboszcz par. Chołojów 1924-1928, administrator par. Szczerzec 1928-1929, administrator par. Podwołoczyska 1929-1935, proboszcz par. Dobrotwór 1935-1944. W ramach ekspatriacji wyjechał na teren archidiecezji krakowskiej: administrator ad personam par. Krzęcin 1944-1945, administrator par. Krzeczów 1946-1949, administrator par. Łopuszna 1949-1955, rezydent w Nowym Targu 1955-1973. Zmarł tamże. Archiwum Kurii Metropolitalnej w Krakowie, Akta Personalne, sygn. B 519, Tabela służbowa ks. Władysława Krzystyniaka, b. d.; Schematismus [Elenchus] archidioecesis Leopoliensis ritus latini 1920-1939, passim; Schematyzm archidiecezji w Lubaczowie 1981 r., Lubaczów 1981, s. 145; Informacje zawarte w edytowanym dokumencie.

${ }^{9}$ Świadczy chociażby o tym załączony do sprawozdania koncept odpowiedzi, który niestety jest uszkodzony, a przez to fragmentaryczny. Zdecydowano się jednak, przy edycji sprawozdania ks. W. Krzystyniaka, dołączyć i jego treść, gdyż pomimo posiadanych defektów wiele aspektów wyjaśnia i uzupełnia.

${ }^{10}$ Krechówka, jako część parafii Machliniec, została w urzędowym schematyzmie archidiecezji lwowskiej wymieniona po raz pierwszy w $1927 \mathrm{r}$.

${ }^{11}$ G. Chajko. O Niemcach i Polakach w Małopolsce Wschodniej, „Kurier Galicyjski”, 2013, nr 11, s. 15 . 
by był on bardziej przejrzysty. Oryginalny dokument przechowywany jest w Archiwum Abpa Eugeniusza Baziaka w Krakowie, w zespole Akt Konsystorskich, w pliku dokumentów oznaczonych sygnaturą 840 .

W edycji zastosowano oryginalny styl autora sprawozdania, stosując przy tym współczesne zasady edycji tekstów i języka polskiego. Literami alfabetu oznaczono uwagi natury edytorskiej, cyframi arabskimi - wyjaśnienia merytoryczne.

$* * * * *$

\section{Sprawozdanie ks. Wladysława Krzystyniaka o stanie rzymskokatolickiej ekspozytury w Machlińcu, Machliniec 21 III 1922 r.}

Sprawozdanie z parafii rz[ymsko]kat[olickiej] Machliniec ${ }^{12}$ dziekanatu [sic!] Stryj dla Kurii Metropolitalnej obrz[ądku] łac[ińskiego] we Lwowie z roku 1921/1922

Najprzewielebniejsza Kurio Metropolitalna,

Stosownie do otrzymanej łaskawie aplikaty z daty Lwów 20 września $1921 \mathrm{r}$. ustanawiającej mnie ekspozytem parafii obrz[ądku] lac[ińskiego] w Machlińcu, po podróży z poprzedniej posady tj. z Toustego ${ }^{13}$, stanąłem w Machlińcu dnia 7 października 1921 r. Po drodze wstąpiłem w Stryju ${ }^{14}$ do Przewielebnego Księdza Dziekana Cisły ${ }^{15}$, jak mi nakazał Jego Ekscelencja Ksiądz Metropolita ${ }^{16}$, i od Księdza Dziekana podówczas zajętego wizytą kanoniczną, otrzymałem obietnicę, że Ksiądz Dziekan przy sposobności tak zwanego Kirchweihu ${ }^{17}$ mnie osobiście odwiedzić i do parafii wprowadzić raczy. Przy kościele czekał na mnie komitet kościelny, który mi oddał klucze od kościoła i plebanii, ciesząc się ogromnie, że

${ }^{a}$ Powyżej, w prawym górnym rogu stronicy, odciśnięta została podłużna pieczęć o treści: „URZĄD PARAFIALNY RZ.-KAT. W MACHLIŃCU” oraz numer dziennika: „L.31/1922”. Sprawozdanie sporządzono ręcznie czarnym atramentem na 28 stronicach czystego papieru formatu austriackiej kancelarii, zszytego w poszyt. Na ostatniej, czystej stronie, Kuria Metropolitalna odcisnęła w prawym górnym rogu pieczęć wpływu o treści: „Praes[tatum] die 30 Martii 1922”. Poniżej zaś niej zamieszczone zostały różne adnotacje: „2759/663”, „Machliniec”, „X. Infułat Czajkowski”, „,urgenter Joz[?]”, „dołączono akta L.157/21”, „,do protokołu nie”, „19/6/22”. W niniejszej edycji źródłowej pominięto sporządzony przez autora sprawozdania spis treści, gdyż podane przez niego numery stron uległy zupełnej zmianie wskutek edycji.

${ }^{12}$ Machliniec - wieś w pow. Żydaczów, woj. stanisławowskie.

${ }^{13}$ Touste - miasteczko i gmina w pow. Skałat, woj. tarnopolskie.

${ }^{14}$ Stryj - miasto powiatowe w woj. stanisławowskim.

${ }^{15}$ Aleksander Cisło (1857-1944) - święcenia kapłańskie w 1882 r. we Lwowie, wikariusz par. Dolina 1882-1889, administrator par. Dolina 1889-1892, proboszcz par. Toki 1892-1904, proboszcz par. Stryj 1904-1944, dziekan dekanatu stryjskiego 1904-1944, prałat papieski, kanonik honorowy Kapituły Metropolitalnej we Lwowie, obywatel honorowy miasta Stryja. Zginął od uderzenia odłamkiem pocisku w Stryju. Schematismus [Elenchus, Catalogus] archidioecesis Leopoliensis ritus latini 1882-1939, passim; Schematyzm archidiecezji w Lubaczowie, Lubaczów 1981, s. 131.

${ }^{16}$ Mowa o abp. Józefie Bilczewskim - metropolicie lwowskim obrządku łacińskiego we Lwowie w latach 1900-1923.

${ }^{17}$ Niem.: Kirchweih - odpust parafialny. 
nareszcie po 2 latach otrzymują własnego księdza. Ja jednak byłem mniej ucieszony, bo nie mogłem zapanować nad smutkiem jaki mnie ogarnął, gdym się spotkał z ludźmi mnie narodowo obcymi, tj. Niemcami i przyjechawszy z czysto polskiej parafii, musiałem od pierwszej chwili mówić po niemiecku, przez co zdawało mi się, że jestem jakimś wygnańcem wśród obcych ludzi i obcego kraju. Nikt się do mnie po polsku nie odezwał, gdyż Niemcy albo po polsku nie umieją, albo choć umieją nie chcą mówić. Ja musiałem na gwałt uczyć się pacierza niemieckiego i innych niemieckich modlitw i wtedy dopiero poznałem, że to prawdziwa ofiara i twardy obowiązek dla polskiego księdza pracować wśród obcych, do tego we własnej ojczyźnie. Może to w pełni odczuć tylko ten, kto osobiście te chwile przeżyje.

Wizyta Przewielebnego Księdza Dziekana

Dnia 16 października przybyć raczył ksiądz dziekan ze Stryja i odprawił uroczystą sumę. Po sumie zwołał komitet kościelny i przypomniał członkom, że obecnie, mając już swego księdza, muszą wobec niego wypełnić wszystkie świadczenia do jakich są obowiązani, tj. muszą dać 24 korce żyta i 81 fur po drzewo dla księdza. Komitet przyrzekł, że parafianie wszystko rzetelnie wypełnią, prosili tylko Księdza Dziekana, by ich nowy ksiądz językiem polskim nie prześladował, damit sie mit der polnischen nich geplagt werden ${ }^{18}$. Ksiądz Dziekan odpowiedział im, że nie będzie ani polskiego kazania, ani polskiej Ewangelii, lecz będzie ksiądz tylko zapowiadał święta i nabożeństwa po niemiecku i po polsku, by polscy parafianie wiedzieli, co się i kiedy będzie w kościele odprawiać. Pozwoliłem sobie wtedy zwrócić Księdzu Dziekanowi uwagę, by przynajmniej dla Polaków czytać Ewangelię polską przed kazaniem, lecz ksiądz dziekan odpowiedział, iż polskiej Ewangelii ani ksiądz Szwarc ${ }^{19}$, mój poprzednik, ani administrator ex currendo $o^{20}$ salezjanin z Daszawy ${ }^{21}$ Ewangelii polskiej nie czytali więc i teraz czytana nie będzie. Ksiądz dziekan ma rzeczywiście na Niemców ogromny wpływ i oni nie nazywają księdza dziekana inaczej jak tylko unser deutsch freudlicher Dechant $^{22}$. Jak się odbyło moje wprowadzenie do parafii: Administrując parafię już z górą 5 miesięcy, poznałem dokładnie tutejsze stosunki, a przy kolędzie poznałem i zbliżyłem się do mych niemieckich i polskich parafian i na tej podstawie po odpowiednim przeciągu czasu, zdecydowałem się niniejsze sprawozdanie zreda-

${ }^{18}$ Niem.: aby z polskim [językiem] nie cierpieli.

${ }^{19}$ Antoni Szwarc (1869-1942) - święcenia kapłańskie w 1897 r. w Zgromadzeniu Redemptorystów, od 1905 r. w archidiecezji lwowskiej, wikariusz par. Zaleszczyki 1905-1906, wikariusz par. Buczacz 1906-1907, katecheta par. Horodenka 1908, ekspozyt w Wierzbicy oraz Tarnoszynie 1908-1911, ekspozyt w Machlińcu 1911-1918 (?), ekspozyt w Turówce 1920?-1922, proboszcz par. Kuropatniki 1923-1926, proboszcz par. Złotniki 1926-1942. Schematismus [...] 1897-1939, passim; Schematyzm [...], s. 128.

${ }^{20}$ Łac.: z dojazdu.

${ }^{21}$ Daszawa - wieś i gmina w pow. Stryj, woj. stanisławowskie. W miejscowości funkcjonowała od 1904 r. parafia, w której obowiązki duszpasterskie pełnili duchowni ze Zgromadzenia Salezjanów.

${ }^{22}$ Niem: nasz niemiecki przyjacielski dziekan. 
gować. Zaznaczam jednak, że piszę je zupełnie bezstronnie sine irae et studio ${ }^{23}$, a jeśli w ciągu dalszym mniej korzystnie oświetlę pewne fakta i osoby i wytknę błędy lub braki, to czynię to jedynie dlatego, by należycie dać wyobrażenie o tej bądź co bądź ciekawej parafii machlinieckiej i o stosunkach, jakich może w innych parafiach naszej archidiecezji się nie spotyka.

\section{Liczba parafian rz[ymsko]kat[olickich] Niemców i Polaków}

Według ostatniego spisu ludności w r. 1921, liczba parafian rzymsko-katolickich w 6, do parafii należących wsiach, wynosiła:

We wsi Machliniec

Izydorówka ${ }^{24}$

Kontrowers ${ }^{25}$

Kornelówka $^{26}$

Nowe Sioło ${ }^{27}$

Wola Obłaźnicka ${ }^{28}$

W 6 wsiach było
524 Niemców

120

121

240

425

200

1630 Niemców
8 Polaków

16

11

133

40

Razem w ogólnej sumie było przy spisie parafian 1838, co w porównaniu ze sumą z roku 1913-go, kiedy według schematyzmu było parafian $1920^{29}$, daje ubytek przez te lata w liczbie 82 parafian.

Ubytek ten thumaczą straty poniesione w czasie wojny, a także i to, że niektórzy przedwojenni parafianie, z parafii wyemigrowali.

\section{Charakterystyka parafian niemieckich}

a) od względem religijnym

Religijność Niemców ściśle jest związaną z ich niemiecką naturą i usposobieniem. Praktyki pobożne wykonują w tym przekonaniu, że jeśli się jest katolikiem, to porządek tego wymaga, by obowiązki katolickie wypełnić. O ile sprzyja pogoda, to na pewno można stwierdzić, że ci którzy tylko mogą, wszyscy są w kościele. Długich nabożeństw i kazań nie lubią w myśl przysłowia, że: der Deutsche liebt lange Wurst und kurze Predigt ${ }^{30}$, co ich najlepiej charakteryzuje. Nie wzruszają się żadnym kazaniem nawet bardzo czułym, i na uczucie w pracy pasterskiej liczyć tu nie można; trzeba rzecz uzasadnić i przekonać rozumowo, wtedy jest skutek. Do sakramentów pokuty i ołtarza w ciągu roku prawie że nikt nie przystępuje; nie pomagają tu żadne perswazje i nauki o pożytkach tych sakramentów. Za moich czasów miałem około 100 osób do spowiedzi przed Bożym Narodzeniem,

\footnotetext{
${ }^{23}$ Łac.: bez gniewu i stronniczości.

${ }^{24}$ Izydorówka - wieś w pow. Żydaczów, woj. stanisławowskie.

${ }^{25}$ Kontrowers - osada wiejska w gm. Ruda, pow. Żydaczów, woj. stanisławowskie.

${ }^{26}$ Kornelówka - przysiółek w gm. Ruda, pow. Żydaczów, woj. stanisławowskie.

${ }^{27}$ Nowe Sioło - wieś w pow. Żydaczów, woj. stanisławowskie.

${ }^{28}$ Wola Obłaźnicka - osada wiejska w pow. Żydaczów, woj. stanisławowskie.

${ }^{29}$ Schematismus [...] 1913, p. 148.

${ }^{30}$ Niem.: Niemiec lubi długą kiełbasę i krótkie kazanie.
} 
a od tego czasu do dziś może 20, nie licząc nowożeńców. W tym względzie mają już wyrobione zdanie, że einmal im Jahre, abergut ${ }^{31}$. Wszyscy natomiast idą do spowiedzi wielkanocnej i wtedy żadnego nie braknie.

Mimo tego rzadkiego przystępowania do spowiedzi, prowadzą ci Niemcy rzecz dziwna, co należy wybitnie podkreślić, prawie wszyscy bardzo przykładne i moralne życie. W sądzie nie widziano pewnie Niemca od 10 lat, chyba [że] w sprawie spadkowej; nie słyszałem dotychczas ani o jednym wypadku bójki lub kłótni, nie tylko na ulicy, ale nawet w domu. Nie słychać prawie przekleństw; tego nie lubią. Młodzież bardzo dobrze i surowo wychowana, nikt z młodzieży wieczorem po ulicy się nie wałęsa, gdyż rodzice na to nie pozwalają. Zabawy odbywają tylko pod okiem matek i ojców. Bez opieki rodziców na zabawę nikt iść się nie odważy, zwłaszcza młodsi niżej 20 lat życia. W ogóle stosunek dzieci nawet starszych do rodziców jest surowy i jakiś patriarchalny. Wola rodziców jest bezwzględnie uszanowaną, co zwłaszcza przy małżeństwach powoduje to, że młodzi żenią się z drugimi osobami nierzadko tylko z woli rodziców, którzy partię wyznaczają.

Życie moralne młodzieży jest ogromnie przykładne; dziecko nieślubne jest tak niezwyczajnym wypadkiem, że np. podczas wojny wśród Niemców nie było jednego. Żony mężów będących na wojnie niecoś sobie niektóre pozwalały, lecz wśród młodzieży żeńskiej nie było nic niemoralnego.

Pić lubią, lecz w miarę. Złodziejstwo Niemcom nieznane. Obecnie z sąsiednich wsi wykradają Niemcom złodzieje rozmaite rzeczy, lecz np. w Machlińcu czysto niemieckiej wsi, można i teraz położyć jakąś rzecz nawet na ulicy, a jest się pewnym, że jej nikt nie tknie. Złodziejem pogardzają więcej niż zwierzęciem i takiego by między sobą nie ścierpieli. Ogólnie można powiedzieć, że są wybitnie naturaliter boni ${ }^{32}$.

b) pod względem narodowym

Zasadniczą w tym względzie cechą, jest wygórowana u nich pycha narodowa. Gdy Niemiec mówi, że ich bin ein Deutscher ${ }^{33}$ robi to $\mathrm{z}$ taką dumą i radością, jakiej u nas ani nie spotkać. Niemcy, gdy jako koloniści tu przybyli, nie byli tak jak obecnie narodowo uświadomieni. Szowinistami zrobiła ich agitacja tzw. Bundu der Deutschen in Galizien ${ }^{34}$, która tak bardzo dała się przedwojennym moim poprzednikom we znaki. O tych wypadkach dużo już poprzednicy moi pisali. Agitacja ta nie przebierała w środkach, a szalała najbardziej krótko przed wojną. Jak

${ }^{31}$ Niem.: raz do roku, lecz dobrze.

${ }^{32}$ Lac.: dobrzy z natury.

${ }^{33}$ Niem.: ja jestem Niemcem.

${ }^{34}$ Niem.: Związku Niemców w Galicji; Pełna nazwa organizacji brzmiała: Związek Chrześcijańskich Niemców w Galicji - założony w 1907 r. we Lwowie z inicjatywy niejakiego Wiedemanna z Bukowiny. Związek wydawał we Lwowie niemieckojęzyczne pismo jako swój organ prasowy, występował z żądaniami przyznania mandatów poselskich do Sejmu Krajowego we Lwowie i Parlamentu Wiedeńskiego oraz aktywnie zajmował się sprawami niemieckiej narodowości w Galicji. G. Smólski, Kolonie i stosunki niemieckie w Galicji, Kraków 1910, s. 5; Ruch wszechniemiecki na Wschodzie, „Goniec Częstochowski”, 1907, nr 264, s. 1. 
poczucie narodowe jest wyegzaltowane, o tym świadczy fakt, że dzieci z I klasy powszechnej nie chcą się uczyć języka polskiego i głośno wołają, że są Deut$s c h e^{35}$, to im tego nie potrzeba. Na każdą najmniejszą nawet sprawę patrzą się tylko pod kątem niemieckiego interesu narodowego. Żyjąc tu z górą już sto lat, nic nie stracili ani ze swego języka, zwyczajów, narodowości. Nie tylko, że sami trzymają się narodowo jak najtężej, lecz owszem w swym sąsiedztwie zniemczyli już dużo polskich i ruskich rodzin tak, że mam Niemców takich jak Johann Hnyda, Maks Batog, Karl Feifruk itp. Niemki wychodzą za Polaków i Rusinów i naturalnie nie uczą zaraz dzieci, lecz na podstawie księgi ślubów zbadałem, że od 43 lat nie było w parafii wypadku, by się Niemiec z Niemką ożenił! O czymś podobnym nie myśli nawet żaden Bursch $^{36}$ niemiecki, gdyż w przeciwnym razie traktowano by go jak zdrajcę i nie miałby co między nimi robić. Tu należy jeszcze dodać ogromną solidarność wewnętrzną, rzetelność i obowiązkowość, wielkie zamiłowanie porządku i czystości w domach, w ubiorze itd. Domy budują jasne, wielkie i wygodne, budynki gospodarcze również przestronne i higieniczne. Największą zaletą to praca nieustanna, niezmordowana, nie nerwowa, lecz powolna, ale ciągła od rana do zmroku. Flegmatyczni w największym stopniu robią wszystko powoli a dobrze. $Z$ wad wymienić należy ów szowinizm i butę narodową, egoizm i materializm oraz pewną chytrość i obłudę.

Politycznie orientują się w ten sposób, że przed upadkiem Austriii ${ }^{37}$ byli zażartymi austriackimi patriotami i podczas wojny dużo dla niej poświęcili mienia i krwi. Z chwilą nastania tzw. Ukrainy ${ }^{38}$, byli jej gorącymi zwolennikami, wiedzieli bowiem aż nadto dobrze o austriacko-ukraińskiej przyjaźni. Żołnierze ukraińscy niemieckich chłopów bardzo respektowali, mówiąc: wy Nimci budete w Ukrainie druhyj narod, a my perszyj - a Polakiw wyrizemo ${ }^{39}$. Tak mi sami Niemcy opowiadali.

Obecnie jeszcze nie wierzą sytuacji i pytają mi się ciągle, czy tu bei uns wird Polen bleiben? ${ }^{40}$ Polski i Polaków nienawidzą, mimo tyloletniej pracy pasterskiej samych księży Polaków, których mieli od 1842 r. w swej parafii. Ksiądz polski kościół im wybudował, księża polscy tak długo i uczciwie tu pracowali, żadne względy nie pomagają. Dla nich istnieją tylko polnische Schweinen ${ }^{41}$ i polnische Hunden $^{42}$. Tak niektórzy głośno wykrzykiwali przy wkroczeniu wojsk polskich po Ukrainie, do mojej parafii.

Obecnie z musu władzy polskiej sumiennie słuchają i wszystkie ciężary najskrupulatniej ponoszą i władzę, z właściwym im instynktem, szanują i poważają.

${ }^{35}$ Niem.: Niemcami.

${ }^{36}$ Niem., właśc.: Bursche - chłopak.

${ }^{37}$ Autor ma zapewne na myśli rozpad Austro-Węgier w $1918 \mathrm{r}$.

${ }^{38}$ Pojęcie odnosi się do samozwańczej Zachodnioukraińskiej Republiki Ludowej - tworu państwowego powstałego na terenie Galicji Wschodniej, istniejącego przez kilka miesięcy 1918-1919 r.

${ }^{39}$ Ukr.: Wy Niemcy będziecie na Ukrainie drugim narodem, a my pierwszym - a Polaków wyrżniemy.

${ }^{40}$ Niem.: u nas pozostanie Polska?

${ }^{41}$ Niem.: polskie świnie.

${ }^{42}$ Niem.: polskie psy. 
Licząc się zaś ze stosunkami, zaczynają dzieci swe więcej niż dawniej uczyć po polsku, naturalnie dla swej korzyści.

Ponieważ obecnie Niemcy w Polsce założyli ogólny związek z siedzibą w Bydgoszczy ${ }^{43}$, więc i moi Niemcy do niego przystąpili i otrzymują co tydzień sporą paczkę Deutsche Zeitung für deutsche Minderheit in Polen ${ }^{44} \mathrm{z}$ Bydgoszczy, gdzie Polacy według tego Zeitung to sami szowiniści, gwałciciele i prześladowcy Bogu ducha jedynie winnych Niemców.

Jeśli Bóg pozwoli i Polska tu zostanie, to jest nadzieja, że ci Niemcy będą tak za 20 lat dobrymi obywatelami, lecz Polakami nie będą nigdy. Czuwają nad tym bowiem bracia z wielkiej Germanii aż nadto silnie i pracy i grosza nie szczędzą, by swym braciom im auslande ${ }^{45}$ dopomagać duchowo i materialnie. Tej tężyzny narodowej niemieckiej nie potrafi chyba nikt osłabić, a zwłaszcza nasz naród, której jej sam prawie nie posiada.

\section{Charakterystyka parafian polskich}

\section{a) pod względem religijnym}

Parafianie Polacy są jak w ogóle polski lud do religii bardzo przywiązani. W praktykach religijnych są więcej od Niemców pilni, gdyż poza spowiedzią wielkanocną, prawie tylko Polacy do spowiedzi i Komunii św. przystępują. Lecz dzieje się tu dziwna rzecz; ci Polacy, którzy jeszcze do kościoła w Machlińcu przychodzą, dosłownie od lat 10, po ustąpieniu z tutejszej parafii ks. Kleina (Szafryńskiego) ${ }^{46}$ Słowa Bożego po polsku ani razu nie słyszeli. Wskutek tego chyba aż nadto dobrze zrozumiałą jest niechęć Polaków do kościoła w Machlińcu, narzekanie na księży i władzę duchowną, że dla Polaków nikt nic nie robi, choć może coś uczynić, że władza nasza duchowna Niemców poważa, popiera, gdyż ci mają i kazania, i Ewangelię i nabożeństwo niemieckie, a polscy parafianie są opuszczeni i pozbawieni prawa słuchania Słowa Bożego w ojczystym języku, na

${ }^{43} \mathrm{~W}$ dniu 8 maja 1921 r. została założona niemiecka organizacja pod nazwą Deutschtumsbund zur Wahrung der Minderheitsrechte in Polen (Związek Niemczyzny dla Obrony Praw Mniejszości w Polsce). Jej celem było podporządkowanie i kontrola wszystkich organizacji niemieckich dążących do umacniania niemczyzny w Polsce. Została rozwiązana przez polskie władze w sierpniu 1923 r. metodą administracyjną, pod zarzutem działalności irredentystycznej. H. Szczerbiński, Deutschtumsbund zur Wahrung der Minderheitsrechte in Polen, w: Encyklopedia Historii Drugiej Rzeczypospolitej, red. zbior., Warszawa 1999, s. 75.

${ }^{44}$ Niem.: Niemiecka gazeta dla niemieckiej mniejszości w Polsce. Prawdopodobnie pod tym określeniem autor sprawozdania ukrył jakiś tytuł czasopisma, gdyż nie zdołano zidentyfikować periodyku o takiej nazwie.

${ }^{45}$ Niem.: na obczyźnie.

${ }^{46}$ Bernard Klein (1875-1937) - święcenia kapłańskie w 1902 r. w Zgromadzeniu Sercanów, od 1905 r. w archidiecezji lwowskiej, wikariusz w par. Suczawa 1905, ekspozyt w Machlińcu 1905-1911, ekspozyt w Burakówce 1911-1915, wywieziony do Kamieńca Podolskiego przez Rosjan 1915-1918, w 1918/1919 r. zmienił nazwisko na Szafryński, administrator par. Turylcze 19191920?, proboszcz par. Łopatyn 1920?-1937. Schematismus [...]1902-1938, passim. 
własnej swej ziemi. Jeszcze za księdza śp. Janora Błażeja ${ }^{47}$ było w Machlińcu po roku 1880-tym, co 3 niedziela polskie kazanie na sumie. Jest to fakt. Następcy księdza Janora tego zwyczaju nie dopilnowali i kazanie polskie wyszło z użycia, mimo, że liczba Polaków się nie zmniejszała, lecz stale zwiększała. Dla jakich celów i korzyści i kto winien jest tej krzywdzie ludu polskiego, Bóg jeden kiedyś osądzi. Za ks. Kleina-Szafryńskiego było kazanie po sumie każdej niedzieli dla Polaków, jednak rzecz wiadoma, ile udręczeń moralnych kosztowało to księdza Kleina. Niemcy później uniemożliwili pobyt ks. Kleinowi i tenże Todtfeind der Deutschen ${ }^{48}$ sam o przeniesienie prosił. Niemcy triumfowali. Nie było już po tym ani słowa polskiego w kościele, bo o polskości następców ks. Kleina i o ich patriotyzmie lepiej nie wspominać. A jakież są skutki zaniedbania Polaków?

Przede wszystkim pierwszy ujemny ten, że Niemcy przekonali się, że niewygodnego sobie księdza mogą według swej woli usuwać, co jeszcze bardziej ich bucie podchlebiło, lecz przez to Niemców zupełnie ani dla Kościoła i religii bardziej nie pozyskano. A Polacy? Ci zaś zaczęli chodzić do cerkwi w Obłaźnicy ${ }^{49}$, chrzcili tam dzieci i ruszczyli się. Skutek tego taki, że dziś rozmaici Jelińscy, Wróble $^{50}$, to zażarci hajdamacy ${ }^{51}$. Ustępliwość wobec Niemców miała więc najgorsze skutki dla naszego obrządku i narodu. A jeśli jeszcze garść Polaków została, to jakiś cud i Opatrzność Boża. O Niemców [u]miał się zawsze ktoś upomnieć, każda ich prośba i protest były uwzględniane, nawet do Wiednia jeżdżono i Niemcy zwyciężali zawsze, a Polacy zostawali na uboczu bez opieki, bez praw, nawet bez Słowa Bożego. W tym wszystkim co się tu i gdzieindziej dla Machlińca robiło, to była tylko polityka wielka i mała, lecz mało było w tym apostolskiej otwartości i nieugiętości. A jak może przedstawiać się stan religijny Polaków, którzy Słowa Bożego nigdy nie słyszą?

Odpowiedź sama chyba każdemu smutna i gorzka się nasunie. Jeszcze tylko kilka lat takiego protegowania Niemców, to ci zostaną jeszcze gorszymi naszymi wrogami, a z Polaków nie zostanie śladu. Potem można im będzie pogratulować, że jednak sprytnie dzieło swe przeprowadzali ci Niemcy, że tak oczyścili swą parafię od polskiej domieszki. Stan obecny jest taki, że kilkoro Polaków przychodzi do kościoła, zwłaszcza ci, którzy po niemiecku rozumieją, reszta chodzi do cerkwi w Obłaźnicy, a kilku do kościoła w Kochawinie ${ }^{52}$. Polacy nazywają mój kościół w Machlińcu po prostu „bóżnicą”; dosadny i pochlebny tytuł.

${ }^{47}$ Błażej Janor (1855-1918) - święcenia kapłańskie w 1879 r. we Lwowie, wikariusz par. Gródek Jagielloński 1879-1881, wikariusz par. Kamionka Strumiłłowa 1881-1883, ekspozyt w Machlińcu 1884-1895, administrator ex currendo par. Sokołów 1885, proboszcz par. Stojanów 18951908, proboszcz par. Łopatyn 1908-1918. Schematismus [...] 1879-1920, passim.

${ }^{48}$ Niem.: śmiertelny wróg Niemców.

${ }^{49}$ Obłaźnica - wieś w pow. Żydaczów, woj. stanisławowskie.

${ }^{50}$ Rodziny bliżej niezidentyfikowane.

${ }^{51}$ Potoczne określenie Ukraińców.

${ }^{52}$ Kochawina - wieś w pow. Żydaczów, woj. stanisławowskie. W miejscowości tej funkcjonowało do drugiej wojny światowej sanktuarium ze słynącym łaskami obrazem Matki Bożej Kochawińskiej. 
b) pod względem narodowym

Stan narodowy Polaków przedstawia się bardzo niekorzystnie. Pożenieni są przeważnie z Rusinkami, czemu nikt nie przeciwdziałał, mówią ze sobą po rusku, ubierają się jak Rusini i ruskie obchodzą zwyczaje. Są to po prostu Rusini łacińskiego obrządku. Jakżeż źle wypada porównanie ich z Niemcami. Lecz czy dziwić się temu, kiedy kościół, ta jedyna polskości ostoja i źródło, swej siły ożywczej $\mathrm{w}$ postaci słowa polskiego $\mathrm{z}$ ambony, im nie dostarczał? Jeśli gdzie, to tu wynarodowienie szybko postępuje, bo Polacy mają za sąsiadów imponujących im wszystkim Niemców i także liczbowo przeważających Rusinów.

\section{Wzajemny stosunek niemieckich i polskich parafian}

Niemcy zamożni, jak na chłopów bardzo inteligentni, imponują tym biednym ciemnym Polakom w każdym względzie. Mimo całej niechęci ku Polakom, Niemcy nie okazują tego zewnętrznie żadnymi wrogimi czynami lub słowami. Są zanadto sprytni i wyrachowani. Owszem z Polakami nawet po polsku rozmawiają, po polsku Pana Boga pochwalą, lecz gdzie zaczyna się granica niemieckiego interesu, tam obcym wara. Wtedy potrafią użyć wszelkich środków by się bronić. Lecz gdzie można zaszkodzić Polakowi, to mu pewnie pierwszy Niemiec zaszkodzi. Grunt polski wykupić, wyzyskać, oto w ten sposób traktują Niemcy Polaków.

Gdy w Nowym Siole kaplica dla Polaków się budowała, ani jeden Niemiec ani jednej cegły, ani ziarnka piasku za darmo nie przywiózł, bo to budowała się polska kaplica, niepomni na to, że połowę kosztów i materiału na kościół w Machlińcu dali polscy panowie i parafianie. A gdy ks. Klein miewał w 1910-[19]11 roku polskie kazania po sumie w Machlińcu, Niemcom tego było za dużo i poradzili sobie w prosty sposób: nie mogąc ks. Kleinowi zamknąć ust, tak wszystkich Polaków, gdy ci z kościoła po kazaniu wyszli, zbili i zmasakrowali, że ci nie mieli już ochoty więcej razy po sumie na polskie zostawać kazanie. Dziś owszem, nikomu nie wzbraniają przyjść do kościoła, lecz w pokorze ducha musi każdy niemieckiego kazania wysłuchać i przysłuchać się, jak to Niemcy pięknie w kościele śpiewają.

\section{Ogólny stan moralny parafian po wojnie}

Wojna przyniosła jedynie to dodatniego, że nie ma w parafii wcale pijaków, bo napoje strasznie drogie. Przyniosła jednak pewne zobojętnienie dla wiary katolickiej i osłabienie jej. Mimo mych próśb i pracy mało jeszcze osób uczęszcza na nabożeństwa do Serca P[ana] Jezusa, do N[ajświętszej] Marii Panny; członkowie róż nie chcą co miesiąc przystępować do spowiedzi itd., a przed wojną było tu inaczej, zwłaszcza za księdza Kleina. Przy tym nie ma już u Niemców niechęci do Kościoła ewangelickiego, co wyrobili stojący tu na kwaterach żołnierze pruscy ewangelicy, których tu może umyślnie na to przez 2 lata trzymano. Przed moim przyjazdem wyraził się jeden Niemiec z Machlińca, że jeżeli księdza nie dostaną, to przejdą na protestantyzm, co stałoby się z łatwością, bo w sąsiedztwie jest wieś protestancka Gelsendorf-Komarów ${ }^{53}$, gdzie jest pastor i kościół protestancki. Przy

${ }^{53} \mathrm{~W}$ rzeczywistości były to odrębne wsie położone tuż obok siebie - obie należały do pow. Stryj w woj. stanisławowskim. 
tym protestantyzm jest uważany u Niemców za kościół narodowy, gdzie już żadne spolszczenie i wynarodowienie nie grozi. Mam w parafii kilku „Freidenkorów”54 jednak nie słyszę by agitowali i gorszyli.

\section{Stosunki wzajemne obecnego ekspozyta z parafianami}

Pożycie ${ }^{55}$ wzajemne do tego czasu przedstawia się ciekawie. Przez 3 miesiące, tj. od października włącznie do stycznia 1922 r. były stosunki nasze jak najlepsze. Muszę na tym miejscu podnieść niezwykłą gościnność i troskliwość o mnie naczelnika gminy Machliniec, Weissa Krzysztofa ${ }^{56}$. Człowiek ten użyczył mi przez tydzień mieszkania i wiktu bezinteresownie, gdyż plebania była pusta bez mebli, a ja nie miałem z początku własnej kuchni. Przez cały czas mego tu pobytu użyczał i użycza mi swej pomocy ile tylko razy tego od niego zażądam. Jest on mimo wszystko człowiekiem bardzo dobrym i uczynnym i moi poprzednicy mają mu również dużo do zawdzięczenia. Do stycznia 1922 r. stosunek mój do parafian był tego rodzaju, że uważano mnie wprawdzie za Polaka, lecz bardzo lubiącego Niemców i patrzącego na Polaków tak, jakby ich nie było. Byłem obdarzany rozmaitymi prezentami bardzo często, począwszy od mleka aż do mięsa. Wszystko Niemcy dla „swego” księdza znosili. Od czasu jednak wprowadzenia polskiej Ewangelii w kościele, mój stosunek do parafian pozostał ten sam, tylko stosunek parafian do mnie uległ znacznej zmianie. Zniknęły przyjemne uśmiechy i piękne oczy i co najpocieszniejsze zniknęły i owe prezenty w postaci wspomnianych smakołyków. Dalej, jak przedtem, są bardzo grzeczni, układni, lecz czuję, że to obłuda, że mnie nie lubią (O tej polskiej Ewangelii mowa później). Z początku obiecywali, że mi grunt (4 morgi) zorzą, w robocie pomogą, dziś o wszystkim zapomnieli. A o mnie jak się wyrażają, o to że: drei Monate war unser Geistliche sehr gut, aber jetzt ist es mit diesem polnischen Evangelium ganz schlimm geworden $^{57}$, albo Hochwürden, alles werden Sie haben, nur muss das polnische Evangelium verschwinden ${ }^{58}$. Obecnie kryzys już przeszedł i powracają dawne stosunki przyjazne, lecz ja mam naoczny przykład, jak Niemcy potrafią uczynić, choć im się nic nie odbiera, a tylko nie pozwala się germanizować Polaków. Można być lubianym, będąc nawet najgorszym szubrawcem, a tylko im w drogę nie wchodzić, pozwalać na krzywdzenie drugich, a znajdzie się i ,przywiązanie” i prezenty, byle tylko ich mit der polnischen nicht plagen ${ }^{59}$.

Oczywiście ja sobie z tej niemieckiej asympatii nic nie robię, wspominam o tym dlatego, by ich oświetlić, że im nie chodzi o chwałę Bożą, tylko o niemczyznę i o niemiecki interes. I jak dawniej zasypywany byłem wprost intencjami mszalnymi, tak teraz, jakby za namową nikt na Mszę św., względnie bardzo rzad-

${ }^{54}$ Określenie od niem.: Freidenkor - wolnomyśliciel.

${ }^{55}$ Wyrażenie archaiczne; tu w znaczeniu: koegzystencja.

${ }^{56} \mathrm{Nie}$ zdołano ustalić bliższych danych biograficznych.

${ }^{57}$ Niem.: przez trzy miesiące nasz duchowny był bardzo dobry, ale teraz bardzo się pogorszyło przez tę polską Ewangelię.

${ }^{58}$ Niem.: Wielebny, wszystko będzie Ksiądz miał, tylko musi polska Ewangelia zniknąć.

${ }^{59}$ Niem.: polskim nie męczyć. 
ko, przyniesie. A gdy do tego ksiądz jeździ do polskich dzieci do Krechówki ${ }^{60}$ i ma zamiar dokończyć kaplicę w Krechówce i w Nowym Siole, no to już takich zbrodni Niemcy mi pewnie nie podarują i ich „sympatia” do mnie będzie stale wzrastać... Przyjechałem do nich z najlepszą wolą, robię dla nich co mogę, przekręcam mój język by im tylko po niemiecku dogodzić, lecz oni sobie tego nie cenią i zamiast cieszyć się, że mają nareszcie księdza, chcieliby bym się jak najprędzej wyniósł. Niech raczej księdza nie będzie, ale nie będzie także jednego słowa polskiego w kościele. Naprawdę Niemcy są zawsze i wszędzie ci sami. Germańska natura się nie zmienia, a wśród nich polski ksiądz, jak Daniel we lwiej jamie. Ja w niczym się wobec nich nie zmieniłem, robię co do mnie należy, a na ich gadanie nie reaguję, owszem jestem lepszy i grzeczniejszy nawet niż przedtem. Aby mi dokuczyć, to gdy byłem po kolędzie, dało mi 2 Niemców, posiadających każdy po 40 morgów ziemi, po $20 \mathrm{~m}$ [are]k p[olskich] kolędy, jakby na drwiny, myśląc, że ja tylko po pieniądze od domu do domu chodzę. Daj mi Boże, bym tylko kaplicę w Nowym Siole i Krechówce dokończył i inne sprawy uregulował, to będę się starał pożegnać ten drogi Machliniec. Tak to za zaniedbania drugich ja muszę być kozłem ofiarnym. Ja nikomu krzywdy nie robię, a oni niech gadają co chcą. Bogu dzięki, że mamy tu polskie rządy, to oni nie mogą tak brykać, bo gdyby tu była jeszcze Austria lub Ukraina, to by tego polskiego księdza już dawno sprzątnęli, swymi intrygami i gadaniem. Przy tej sposobności proszę o pozostawienie mnie mimo wszystko w Machlińcu, gdyż trzeba tu księdza koniecznie, by kaplice w Nowym Siole i Krechówce dokończyć i inne sprawy uregulować, o czym będzie później mowa. Sprawy te są tak ważne i piekące, że dla samego ich zrealizowania, warto tu pozostać, a niemieckie gadanie i krzyk puścić mimo uszu.

\section{Sąsiedzi i współżycie ${ }^{61}$}

Poważnymi mymi sąsiadami świeckimi to hrabiostwo Dzieduszyccy ${ }^{62}$ w Izydorówce. W Machlińcu byli wszystkiego 2 razy w kościele. Poza oficjalnym przedstawieniem się, u nich nie byłem. W niczym mi nie pomagają, a za drzewo opałowe policzyli mi jak każdemu innemu. Przy dokończeniu kaplicy w Nowym Siole i Krechówce będą mi pomocni, zwłaszcza, że za ich głównym staraniem kaplice te stanęly.

Sąsiadami duchownymi to przede wszystkim księża salezjanie w Daszawie, gdzie jeżdżę spowiadać wychowanków co miesiąc, lub częściej. Przy tej sposobności muszę zaznaczyć, że opowieści o obdzieraniu parafian w Machlińcu i o ich chciwości, są przez kogoś grubo przesadzone. Niemcy mają bogactwa ogromne,

${ }^{60}$ Krechówka - osada wiejska, gm. Sokołów, pow. Stryj, woj. stanisławowskie.

${ }^{61}$ Archaizm: koegzystencja, obustronne relacje.

${ }^{62}$ Majątkiem w Izydorówce, w okresie międzywojennym, zarządzał Konstanty Dzieduszycki (1884-1964), ur. w Izydorówce, w okresie pierwszej wojny światowej aktywny uczestnik walk o niepodległość Polski, dwukrotnie adiutant marszałka Józefa Piłsudskiego, poseł na Sejm II RP 1928-1930, senator RP 1935-1938. Był właścicielem majątku Hyżne w pow. rzeszowskim, a także pełnomocnikiem rodzinnych majątków Izydorówka, Sulatycze i Lachowice o łącznej powierzchni 1.670 ha. Zmarł w Londynie. Dzieduszycki Konstanty, w: Posłowie i senatorowie Rzeczypospolitej Polskiej 1919-1939. Stownik biograficzny, t. 1, red. A.K. Kunert, Warszawa 1998, s. 451. 
to powinni byli jeszcze więcej dawać tym, którzy nic nie mają, tj. salezjanom, wychowującym ubogą młodzież.

W Kochawinie i Antoniówce bywam rzadko, bo nie mam swych koni, a o konie i furę w Machlińcu bardzo trudno.

VII. O stanie:

a) kościoła

Kościół wybudowany przez ks. Drozdowskiego ${ }^{63}$ w r. 1862 dziś zewnętrznie przedstawia się dość mizernie. Ściany z tynku miejscami odrapane, dach blaszany podziurawiony, trzeba jak można najprędzej kościół otynkować i dach naprawić. Wewnętrznie przedstawia się miło i schludnie, lecz nadto może skromnie, lecz Niemcy ozdób wielu nie lubią. Ściany zdałoby się również pomalować, bo są już zaprószone.

Dzwon jest jeden, 2 zabrali Austriacy, lecz czynię starania by ich na powrót otrzymać, gdyż są na składzie przy Województwie w Krakowie, jak nam prywatnie doniesiono.

Paramenty kościelne nieliczne i nieświeże, lecz i ofiarność niemiecka na te cele niewielka.

b) plebanii i budynków gospodarczych

Budynek plebański postawiony przez ks. Kleina jest bardzo wygodny, obszerny, suchy i przez wojnę nic nie zniszczony. W piwnicy tylko wieczny staw, gdyż tutejsza gleba ogromnie przepuszcza wodę, tak, że piwnic tu nie ma, a plebańska nie do użytku.

Budynek gospodarczy zupełnie odpowiedni na 4-morgowe gospodarstwo plebańskie. Przez kwaterunki wojskowe stajnie i stodoła nieco zniszczona, lecz z tą wiosną komitet szkody naprawi.

c) gruntu plebańskiego

Obecny grunt plebański składa się z jednego kawału 4-morgowego ziemi 4 klasy i 1 1/4 morgowego ogrodu. Grunt pochodzi z fundacji mszalnych, resztę kupił ks. Klein od gospodarzy. Gdy tu przybyłem, pole zastałem leżące odłogiem. W ogrodzie i w polu nic w jesieni nie zasiałem, bo to było niemożliwym z braku czasu i nawozu. W tym roku grunt do spółki za połowę wydzierżawię, a ogród sam uprawię. Pole jest wyjałowione, gdyż je nie uprawiano przez 2 lata i nie nawożono. W ogrodzie jest kilkanaście drzew owocowych. Uposażenie gruntowe ekspozyta w Machlińcu przechodziło rozmaite pomyślne i niepomyślne koleje. Koniec z końcem, ma dziś ekspozyt owe 4 morgi pola i ów ogród.

${ }^{63}$ Władysław Drozdowski (1829-1895) - święcenia kapłańskie w 1853 r. we Lwowie, wikariusz w par. Kaczanówka 1853-1858, ekspozyt w Machlińcu 1858-1862, kapelan kapelanii Olejów 1863-1881, proboszcz par. Petlikowce Stare 1881-1894, proboszcz par. Budzanów 1894-1895. Schematismus [...] 1853-1896, passim. 
d) materialnych stosunków ekspozyta

Położenie materialne ekspozyta jest takie, że ekspozyt nie należy ani do bogaczów, ani do biedaków. Ów majątek 4-morgowy z ogrodem jest śmiesznie mały w porównaniu z uposażeniami gdzieindziej znajdujących się ekspozytur. Jednego konia i krowę i 2 wieprzaki można jeszcze wychować, więcej absolutnie nie. Sytuację ratuje to, że parafia daje rocznie 24 korce żyta (na papierze) i dostarcza 80 fur $^{64}$ po drzewo dla księdza. Ponieważ zaś każdy Niemiec ma przeciętnie 15 morgów ziemi, co jest prawdziwym bogactwem, dlatego ksiądz może więcej brać za iura stolae ${ }^{65}$ i na Mszę św. niż w biednych polskich wsiach. Jeśli się zważy, że tej zimy za samo drzewo dałem 67 tysięcy marek, a inne wydatki są olbrzymie, więc położenie materialne moje nie jest do pozazdroszczenia. Niemcy zaś tak się zachowują, jakby na to szczęście machlinieckie, nie jednego, lecz 100 kandydatów w każdej chwili znaleźć mogli.

e) kancelarii parafialnej

Kancelaria parafialna jest $\mathrm{w}$ najkorzystniejszym stanie. Księgi wszystkie mimo zawieruchy wojennej nie zniszczone, jak najlepiej zachowane, i w czasie całej wojny normalnie prowadzone. Stało się to dzięki temu, że cały czas wojny, ekspozyci z parafii się nie wydalali. Przez ostatnie 2 lata zakradł się nieporządek do kancelarii, lecz wszystko już znowu wpisałem, dokumenty i akta uporządkowałem. Panuje tu ten zwyczaj, że wszelkie wydatki na kancelarię, przybory, druki i inne rzeczy kancelaryjne ponosi sam ksiądz, który musi owe wydatki pokrywać z dochodów kancelaryjnych.

\section{Sprawa polskiej Ewangelii}

Odpis pisma odczytanego przez księdza ekspozyta w kościele rz[ymsko] kat[olickim] w Machlińcu w dniu 6 stycznia 1922 w sprawie zaprowadzenia po niemieckiej, także i polskiej Ewangelii:

Meine Pfarlinge! Ich als Eksposit der Kirche in Machliniec kann ich alles, was des Gottesdienstes und der Kirchenzeremonien anbelangt, ohne meine Parafianer $\mathrm{zu}$ fragen, ab ihnen das gefällt oder nicht, anzuordnen. In diesem bin ich nur vor meinen geistlichen Vorgesetzten verantwortlich. Aber wie ein Vater, wie er zum Beispiel et was wichtiges zu machen vornimmt, davon seinen Kindern sagt, ebenso auch ich, als ihr geistlicher Vater will ich nichts machen, ohne dass sie davon nicht wissen sollen. Die Sache ist folgend: Ich habe von anderen Geistlichen, sowie von der Seite der interessierten Personen sich erkundigt, dass unsere Parafianer der polnischen Nationalität und insbesondere von Nowe Sioło und Wola Ołaźnicka allgemein in ihre Pfarrkirche nicht gehen wollen, weil sie sich in unserer Kirche ganz fremd fühlen, und nichts vom Gottesdienste und Predigt verstehen. Ich habe auch Gert, dass sie an Sonn- und Feiertagen in die griechisch-katholische Kirche nach Obłaźnica sich begeben und dort dem griechisch-katholischen Gottesdienste und Predigt beiwohnen, welche ihnen verständlich ist. Dadurch ist es dazuge-

\footnotetext{
${ }^{64} \mathrm{~W}$ początkowej części dokumentu autor memoriału wspomina o 81 furach.

${ }^{65}$ Łac.: dochody prawne, parafialne.
} 
kommen, dass viele unsere Parafianer der polnischen Nationalität von unserer römisch-katholischen Kirche abgefallen sind, und jetzt droht auch die Gefahr, dass sie immer abfallen werden, solange sie eigene Kapelle in Nowe Sioło nicht besetzen [?]. Solchen Zustand, ich als hiesiger Seelsorger und als römisch-katholischer Geistliche, kann ich mehr absolut nicht dulden. Ich bin hier von meinem Hochwürdigsten Erzbischof dazu hier gesendet, um sich um die Erhöhung und Interesse der römisch-katholischen Kirche zu kümmern. Dass ist meine erste und wichtigste Pflicht, welcher ich mit Hilfe Gottes meine ganzen Kräfte opfern werde. Ich bin hier nicht deswegen gekommen um in der Kirche die Deutsch oder Polnischnationalen Interesse zu fordern, nur bin hier dazu gekommen, um meine Parafianer ob sie Deutsche oder Polen sind zu Jesu Christus unserem einzigen und gemeinsamen Herrn zu führen. Die Parafianer der deutsche Nationalität sind In der Pfarrei Machliniec in überwiegender Zahl, und deswegen haben sie das gebührende Recht in unserer Pfarrkirche die deutsche Predigt zu hören, deutsche Kirchenlieder zu singen, und allgemein dem Gottesdienste den deutsche Charakter zu geben, denn man kann nur in der Muttersprache den lieben Gott loben und das Wort Gottes gut und mit Nutzen verstehen. Dieses gebührende Recht kann und will ihnen niemand abnehmen. Aus demselben Grunde aber, nach der christlichen Gerechtigkeit, müssen sie zusagen und erkennen, dass auch unsere Parafianer der polnischen Nationalität auch das gebührende Recht haben in ihrer d. h. in unserer Pfarrkirche, wenigsten paar Worte in ihrer Muttersprache zu hören und zu verstehen. Gegen dieses Recht kann kein verständiger und wahrer, nicht durch das Nationalschowinismus angesteckter Katholiker, etwas dagegen haben. All dieses habe ich betrachtet und bin als hiesiger Seelsorger und römisch-katholischer Geistliche zu dieser Überzeugung gekommen, und mein Gewissen hat mir befahlen, meinen Parafianern der polnischen Nationalität wenigstens das zu machen, um sie zu unsere römisch-katholische Kirche herbeizuziehen, dass ich an jedem Sonn - und Feiertage nach dem deutschen, auch das polnische Evangelium lesen werde. Dass ist die Intention meiner geistlichen Vorgesetzten, und auch meine Kräftigste und unwiderberufene Absicht. Gott bewahre euch meine Parafianer weder Deutsche oder Polen in diesem, was ich vornehme etwas politisches, oder nationales zu verdächtigen. Denken sie auch nicht, dass ich dies für die Polen von Krechówka vornehme, denn sie sind keine unseren Parafianer, und ich labe keine Absicht nationale Zwistigkeit in der Kirche veranstalten, wie es schon in jener Zeit war. Werden sich vielleicht solche Parafianer finden, welche meine Absicht falsch verstehen, bei welchen ich die Sympathie verlieren werde-deswegen, trotzdem aber muss ich ohne auf das zu achten meine Pflicht nach der Gerechtigkeit erfüllen. Wer jemand meint, dass ich durch das polnische Evangelium polonisieren kann, so ist es sehr traurig mit Nationalgefühl solcher Person; denn ich als Pole, möchte ich sogar in Berlin wohnen und kein polnisches Wort hören, trotzdem werde ich immer Pole bleiben. Wer jemand auch denkt, dass ich dies aus Feindlichkeit gegen die Deutschen vornehme, so konnte sich schon jeder überzeugen, ob ich ein Feind 
der Deutschen bin. Also von heute wird immer nach dem deutschen, am jeden Sonn - und Feiertage, auch das polnische Evangelium gelesen ${ }^{66}$.

Machliniec, 6 I 1922

ks. Władysław Krzystyniak

Rz[ymsko]kat[olicki] ekspozyt

${ }^{66}$ Niem.: Moi parafianie! Jako pełniący obowiązki proboszcza kościoła w Machlińcu mogę nakazać wszystko, co dotyczy nabożeństw i ceremonii kościelnych, nie muszę się pytać moich parafian, czy im się to podoba, czy nie. Do tego jestem zobowiązany jedynie wobec moich duchownych przełożonych. Pragnę jednak zachować się jak ojciec - wasz ojciec duchowny - który planując na przykład zrobić coś ważnego, chce, aby jego dzieci o tym wiedziały. Sprawa jest następująca: Dowiedziałem się zarówno od innych duchownych, jak i od zainteresowanych osób, że nasi parafianie narodowości polskiej, zwłaszcza z Nowego Sioła i Woli Obłaźnickiej, nie chcą uczęszczać do swojego kościoła parafialnego, ponieważ czują się w naszym kościele zupełnie obco i nie rozumieją nic z nabożeństw i kazań. Słyszałem również, że w niedzielę i święta, chodzą do greckokatolickiego kościoła w Obłaźnicy i tam przysłuchują się greckokatolickim nabożeństwom i kazaniom, które są dla nich zrozumiałe. Doprowadziło to do tego, że wielu naszych parafian narodowości polskiej odeszło od naszego Kościoła rzymskokatolickiego, a teraz grozi nam jeszcze niebezpieczeństwo, że będą dalej odchodzić, dopóki nie będą posiadali własnej kaplicy w Nowym Siole. Jako tutejszy duszpasterz i duchowny rzymskokatolicki absolutnie nie mogę takiego stanu tolerować. Zostałem przez Jego Eminencję Arcybiskupa tutaj po to posłany, aby troszczyć się o rozwój i zainteresowanie Kościołem rzymskokatolickim. Jest to mój pierwszy i najważniejszy obowiązek, któremu z pomocą Bożą poświęcam wszystkie moje siły. Nie przybyłem tu dlatego, aby w kościele popierać narodowe interesy niemieckie lub polskie, lecz po to, by moich parafian, nieważne, czy są Niemcami, czy Polakami, prowadzić do Jezusa Chrystusa, naszego jedynego i wspólnego Pana. Parafianie narodowości niemieckiej stanowią w parafii Machliniec przeważającą większość i dlatego posiadają należne prawo do słuchania w naszym kościele parafialnym kazań w języku niemieckim, do śpiewania pieśni po niemiecku i ogólnie do nadania nabożeństwom charakteru niemieckiego, ponieważ jedynie w języku ojczystym można dobrego Boga wielbić oraz rozumieć dobrze i z korzyścią Słowo Boże. Tego należnego prawa nikt nie może i nie chce ich pozbawiać. Jednak na podstawie tego samego powodu, według sprawiedliwości chrześcijańskiej, muszą oni się zgodzić i uznać, że nasi parafianie narodowości polskiej również posiadają należne prawo w swoim tzn. w naszym kościele parafialnym, usłyszeć i zrozumieć przynajmniej kilka słów w swoim języku ojczystym. Żaden katolik, niezarażony narodowym szowinizmem, nie może znaleźć zrozumiałego i prawdziwego powodu przeciw temu prawu. Wszystko to rozważyłem w swoim sumieniu i doszedłem do przekonania jako tutejszy duszpasterz i rzymskokatolicki duchowny, aby dla moich parafian narodowości polskiej zrobić coś, co przyciągnie ich do naszego kościoła rzymskokatolickiego, a mianowicie aby przynajmniej w czasie niedziel i świąt po niemieckiej Ewangelii, czytać ją również po polsku. Jest to zarówno intencją moich duchownych przełożonych, jak i moim najsilniejszym i nieodwołalnym zamiarem. Niech Bóg broni was, moi parafianie, czy to polscy czy niemieccy, przed tym, aby podejrzewać w tym co planuję, jakiś zamiar polityczny lub narodowy. Proszę też nie myśleć, że robię to dla Polaków z Krechówki, ponieważ oni nie są naszymi parafianami, a ja nie zamierzam doprowadzać w kościele do narodowego rozdwojenia, jak to już w tamtych czasach bywało. Nawet jeżeli znajdą się parafianie, którzy źle zrozumieją mój zamiar, których sympatię z tego powodu stracę, mimo to muszę spełnić mój obowiązek sprawiedliwości. Jeżeli ktokolwiek uważa, że mogę polonizować przez polską Ewangelię, smutne musi być poczucie narodowości u takiej osoby; ponieważ ja jako Polak mógłbym mieszkać w Berlinie i nie słyszeć ani słowa po polsku, a mimo to zawsze pozostałbym Polakiem. Jeżeli ktoś uważa, że robię to z wrogości do Niemców, to każdy mógł się już przekonać, czy jestem wrogiem Niemców. Podsumowując: od dzisiaj, w każdą niedzielę i każde święto, po niemieckiej Ewangelii będzie zawsze czytana również Ewangelia polska. 
Na początku wyznaję szczerze, że zaprowadziłem czytanie polskiej Ewangelii wbrew radzie Księdza Dziekana, danej mi przy wprowadzeniu mię do Machlińca w październiku $1921 \mathrm{r}$. Lecz pomimo tego, wyż[ej powiedzianego, czyż] mogłem uczynić inaczej? Sumienie i sprawiedliwość nakazywały mi, by tym opuszczonym polskim parafianom, przynajmniej w niedzielę dać choć jedno ziarnko Słowa Bożego w postaci Ewangelii. Uczyniłem, co tylko w najmniejszym stopniu uczynić wypadało, gdyż zdawałem sobie jasno sprawę, że wprowadzenie kazania polskiego byłoby w danych warunkach już przeciągnięciem struny. Ale Ewangelia polska była konieczna, gdyż w parafii jest z górą 200 polskich dusz i te, jak dotychczas, miałyby być pozbawione nawet Ewangelii, tylko dlatego, że to się Niemcom i ich protektorom nie podobało? Nie mogłem inaczej postapić, jak tylko tak, w przeciwnym razie przestałbym sam sobie wierzyć, że jestem wysłannikiem Tego, który rzekł: Idźcie i nauczajcie wszystkie narody ${ }^{67}$.

W piśmie niemieckim wyżej przytoczonym, zdaje mi się, że dobrze potrzebę tej Ewangelii uzasadniłem; chciałem Niemcom wykazać, że przez to ich prawa w niczym uszczuplone nie będą i usprawiedliwiłem się przed nimi dlaczego to robię, choć mogłem bez wszystkiego Ewangelię zacząć czytać. Łudziłem się, że to katolicy, którzy mnie zrozumieją i słuszność przyznają; niestety, widzę, że to tylko Niemcy szowiniści pierwszej klasy, którzy za te parę polskich słów zapłonęli ku mnie głęboką niechęcią, uzewnętrznioną w bojkocie materialnym. Hochwürden, alles was Sie brauchen werden Sie haben, nur dies polnische Evangelium muss verschwinden $^{68}$ - oto taka prawdziwie niemiecka brutalno-chamska zemsta. Dzięki Bogu bez ich pomocy się obejdę i ustąpić nie myślę i póki Polacy nie wykończą kaplicy w Nowym Siole Ewangelię polską przynajmniej będę zawsze czytał.

Czemu poprzednicy nie szanowali zwyczaju polskiego kazania co 3 niedzielę; czemu ustąpili z praw im przysługujących? To będzie dla mnie zagadką, a może powyższe niemieckie zdanie o wszystkim rozstrzygało?

Czym oni mnie nie straszyli i Księdzem Dziekanem i Księdzem Biskupem, a ja im powiedziałem: jedźcie, będę widział z czym wrócicie. Nie pojechali nigdzie, bo znają swe nieczyste sumienie, no i co najważniejsze czują, że już nie ma das $k$. u. $k$. Vaterland ${ }^{69}$, więc trzeba cicho siedzieć.

Gdyby tak ktoś był publicznie to ogłosił, że lud polski na własnej ojczystej ziemi był pozbawiony w swym kościele parafialnym, który pomagał budować, nawet Ewangelii polskiej, byłby to naprawdę skandal.

Przyznaję się i do tego, że chciałem postawić swoje władze duchowne przed faktem dokonanym, co uważam po prostu za grzech, lecz myślałem i co mi inni współbracia radzili, że to będzie dla obu stron droga najwygodniejsza, za co jednak najpokorniej przepraszam. Najpokorniej ośmielam się jednak mniemać, że Najprzewielebniejsza Kuria czytaniu Ewangelii polskiej się nie sprzeciwi i mój postępek zaaprobuje.

${ }^{67}$ Cytat zaczerpnięty z Ewangelii św. Mateusza (Mt 28,19).

${ }^{68}$ Niem.: Wielebny, wszystko co Ksiądz będzie potrzebował, będzie Ksiądz miał, tylko polska Ewangelia musi zniknąć.

${ }^{69}$ Niem.: c. i k. [cesarskiej i królewskiej] Ojczyzny. 
Byłoby rzeczą ze wszech miar odpowiednią, gdyby Najprzewielebniejsza Kuria najłaskawiej raczyła wystosować pismo pod adresem ekspozyta w Machlińcu, pismo, aprobujące mój krok i orzekające, iż póki kaplica dla Polaków w Nowym Siole ukończoną nie będzie, póki więc ci będą chodzić do kościoła w Machlińcu, tak długo będzie czytana po polsku w niedziele i święta przynajmniej Ewangelia. I to również w aktach swych najłaskawiej zanotować raczyła.

Pismo takie wzmocniłoby ogromnie moją pozycję a Niemcy poznaliby, że jeśli im praw się nie uszczupla, to nie mają prawa krzyczeć, gdy się innym chce tylko sprawiedliwość wyświadczyć. Niemcy mają i kościół swój, nabożeństwa niemieckie, kazania, nauki, pieśni, modlitwy publiczne po niemiecku, w szkołach język niemiecki wykładowy, chcieliby jeszcze by i Polacy po niemiecku mówić zaczęli i w niczym Niemcom nie przeszkadzali.

\section{IX. a) Szkoły w parafii}

Szkoły w parafii są wszystkie niemieckie, a jedna tylko polska w Nowym Siole. W poniedziałek udzielam nauki w Machlińcu, rano i popołudniu, we wtorek jeżdżę do Nowego Sioła do szkoły niemieckiej i polskiej, we środę do prywatnej „Deutsche Bundeschule" 70 do Izydorówki, we czwartek do Kornelówki, w piątek udzielam nauki w Machlińcu, a od miesiąca jeżdżę w sobotę do polskiej szkoły poza parafialnej we wsi mazurskiej Krechówce, o co mnie mazurzy prosili, gdyż ich ksiądz ze Sokołowa ${ }^{71}$ nigdy do szkoły przyjechać nie może. Do drugiej „Bundeschule" w Woli Obłaźnickiej nie jeżdżę, bo Niemcy fury nie przysyłają. Religii uczy tam nauczyciel Niemiec katolik. W Machlińcu, Nowym Siole uczą Polki, zaś w Izydorówce, Kornelówce i Woli Obłaźnickiej uczą Niemcy. Wszystkie dzieci niemieckie mają szkoły, polskie także, z wyjątkiem szkoły we Woli Obłaźnickiej, gdzie polskie dzieci do szkoły prywatnej niemieckiej nie chodzą, bo duża opłata szkolna, a Polacy biedni. Będę się starał dla tych dzieci wyjednać z TSL ${ }^{72}$ jakąś pomoc i założyć dla nich szkółkę TSL. Dzieci przez lata wojny są zaniedbane religijnie, robię co mogę by to naprawić. Szkody naprawiono przy sposobności ostatniej wizyty kanonicznej w $1921 \mathrm{r}^{73}$, do której bardzo dobrze przygotowano dzieci z katechizmu, dzięki księżom salezjanom i nauczycielkom miejscowym.

\footnotetext{
${ }^{70}$ Niem.: Niemieckiej Szkoły Związkowej.

${ }^{71}$ Sokołów - wieś i gmina w pow. Stryj, woj. stanisławowskie. W miejscowości tej od $1520 \mathrm{r}$. funkcjonowała rzymskokatolicka parafia.

${ }^{72}$ Towarzystwo Szkoły Ludowej - organizacja oświatowa, istniejąca od 1891 r. w Krakowie, której zadaniem była początkowo obrona ludności polskiej przed wynarodowieniem, a po odzyskaniu niepodległości wszechstronna działalność oświatowo-kulturalna. Obejmowała swoim zasięgiem południowe i południowo-wschodnie obszary kraju. L. Zasztowt, Towarzystwo Szkoły Ludowej, w: Encyklopedia Historii Drugiej Rzeczypospolitej, red. zbior., Warszawa 1999, s. 462.

${ }^{73}$ Wizytacja miała miejsce 5 września 1921 r. Ekspozyturę odwiedził wówczas bp Bolesław Twardowski. G. Chajko, Arcybiskup Bolestaw Twardowski (1864-1944) metropolita lwowski obrządku łacińskiego, Rzeszów 2010, s. 118.
} 
b) Listy pasterskie i rozporządzenia oraz odezwy

Ponieważ nie władam niemieckim językiem, a kazanie muszę czytać, nie mogę zatem Niemcom podawać do wiadomości polskich listów pasterskich, długich rozporządzeń i odezw. Przetłumaczyć ich nie umiem, do czego zresztą nie mam czasu; wskutek tego np. ostatniego listu pasterskiego biskupów polskich o małżeństwie ${ }^{74}$, mimo polecenia, nie czytałem. Rozporządzenia streszczam, a odezw w duchu narodowym (np. z okazji wyboru papieża ${ }^{75}$ ) nie czytam zupełnie, by Niemców nie drażnić. W tym względzie nie wiem jak mam postąpić, aby wykonać polecenie mej władzy, kiedy to czasem jest niemożebnym, albo ze względu na lokalne stosunki niestosownym?

c) Wezwanie „Królowo Korony Polskiej” w litanii loretańskiej

Według obowiązujących w naszej archidiecezji przepisów, do litanii loretańskiej winno się dodawać wezwanie „Królowo Korony Polskiej” ${ }^{\prime}$. Do tego czasu nie dodawałem tego nigdy, bo zaraz po przybyciu do Machlińca dowiedziałem się, że z jednego księdza, który to już dawniej robił, Niemcy się śmiali i dziwili się, że wie kann Mutter Gottes Königin der Polen sein, warum nicht der Deutschen ${ }^{77}$ ? Aby więc nie narażać litanii na pośmiewisko, wezwania nie dodawałem. Z jednej strony chciałbym przepisy kościelne wykonać, z drugiej zaś nie mogę dopuścić do szyderstw z litanii loretańskiej; rzecz ta wymaga wyjaśnienia i ustalenia ${ }^{78}$.

\section{Sprawa tak zwana „zbożowa”}

a) Jak się przedstawia danina zbożowa parafian dla ks. ekspozyta w roku obecnym?

W jesieni, gdym przybył do Machlińca, komitet kościelny przyrzekł solennie księdzu dziekanowi, że parafianie wszystkie daniny dla księdza uiszczą. Danina ta przedstawia się tak, że parafianie dają księdzu corocznie 23 korce żyta w ziarnie i dostarczają 81 fur do lasu po drzewa opałowe dla księdza.

${ }^{74}$ List pasterski biskupów polskich o malżeństwie do duchowieństwa i wiernych, 20 października $1921 \mathrm{r}$.

${ }^{75}$ Autor sprawozdania miał zapewne na myśli okólnik abpa Józefa Bilczewskiego, skierowany do duchowieństwa i wiernych archidiecezji. Metropolita w kilku akapitach przedstawił w nim w pompatyczny sposób m.in. związki nowego Ojca św. z Polską, nie pomijając też cytatów samego papieża o Polsce i Polakach. J. Bilczewski, Okólnik do Duchowieństwa i Wiernych Archidiecezji lwowskiej ob. łac. z powodu wyboru Piusa XI, „Kurenda Kurii Metropolitalnej obrządku łacińskiego we Lwowie", 1922, nr 2, s. 7-8.

${ }^{76}$ Wezwanie to zostało dodane do Litanii Loretańskiej dzięki inicjatywie ówczesnego arcybiskupa lwowskiego obrządku łacińskiego, obecnie świętego, Józefa Bilczewskiego. Na jego też wniosek, w 1920 r., papież Benedykt XV zezwolił na dodanie wezwania „Królowo Polski” względnie „Królowo Korony Polskiej” do w/w Litanii. Inwokacja «Królowo Korony Polskiej» w Litanii Loretańskiej, „Kurenda Kurii Metropolitalnej obrządku łacińskiego we Lwowie”, 1920, nr 3, s. 7-8.

${ }^{77}$ Niem.: skoro może Matka Boża być Królową Polski, dlaczego nie Niemiec?

${ }^{78}$ Obok ołówkiem bp. Twardowski zanotował: „W czasie wizyty kanon[icznej] uroczyście sami przyrzekli, że zboże dadzą - sądzę, że poczciwy wójt Weiss mógł to wykonać. †B[oleslaus] Ep[iscopus]" 
Rzeczywiście co do owych fur, to ile ich tylko zażądałem, tyle fur po drzewo zawsze pojechało i drzewo mam już zwiezione tak, że do zimy następnej wystarczy.

Co do owego zsypu zboża, to uiściły go wieś Machliniec, Izydorówka-Kontrowers; Kornelówka w 3 częściach, a gmina Nowe Sioło i Obłaźnicka Wola nie dały nic. Zamiast 23 korcy, dostałem tylko 18 korcy żyta. To niedawanie zboża w całej należnej ilości, powtarzało się tu od wielu lat. Poprzednicy nie upominali się o wszystko; skutek tego był taki, że ci, którzy jeszcze dawali, zaczęli dawać mniej lub nie dawali wcale, widzieli bowiem, że niedającym nic złego się nie dzieje; tak szło z roku na rok coraz mniej, a nareszcie księdzu Szwarcowi w roku 1919-tym nie dano zgoła nic. Opornych wzywałem już kilkanaście razy prywatnie i z ambony by zboże przynieśli, lecz to nic nie pomagało: w ostatnią zaś niedzielę zapowiedziałem, że kto do tygodnia zboża nie przyniesie, tego wprost do sądu zaskarżę, czego również domagają [się] ci parafianie, którzy zboże oddali. Pogróżkę tą koniecznie trzeba wykonać, gdyż sprawa jest ze względu na następców bardzo ważna i również jestem pewny, że gdy się opornym pokaże, że zboże dać muszą, to i w następnych latach zboże oddadzą, a chętni nie będą się do daniny zrażać i wyrzekać, że myśmy dali, a tamci nie i mimo tego nic się im nie dzieje.

W tym celu pozbierałem już nazwiska niechcących dać i oddam w krótkim czasie sprawę do sądu, bo tu innego już środka nie można wymyśleć, jak tylko udać się do sądu, celem wyegzekwowania owej daniny zbożowej od parafian wcale nie biednych, lecz bogatych i zamożnych. Niektórzy nawet zuchwale odpowiadają, że mi zboża nie dadzą, bo księdzu „nie potrzeba”, a i tak im za to nikt nic $\mathrm{z}$ tego nie zrobi.

b) Jak sprawa zbożowa winna być na nowo uregulowaną?

Stan faktyczny: W roku 1858 zobowiązały się następujące gminy do daniny zbożowej na rzecz księdza $w$ ten sposób, że:

Gmina Machliniec daje z $50 \mathrm{Nr}$ po 1 ćwierci tj. 50 ćwierci tj. $12 \frac{1}{2}$ korca

Gmina Kornelówka daje z $21 \mathrm{Nr}$ po 1 ćwierci tj. 21 ćwierci tj. $5 \frac{1}{4}$ korca

Gmina Nowe Sioło daje z $31 \mathrm{Nr}$ po $1 / 2$ ćwierci tj. 15/2 ćwierci tj. 33/4 korca

Gmina Izydorówka daje z $8 \mathrm{Nr}$ po 1 ćwierci tj. 8 ćwierci tj. 2 korce

Gmin 4 daje razem

23 i $1 \frac{2}{2}$ korcy

Od roku jednak 1858 stosunki uległy znacznej zmianie, tak, że danina zbożowa nie odpowiada już dziś sprawiedliwości i jej tytuł prawny obecnie jest co do niektórych gospodarzy i gmin przestarzały i za szczupły, a mianowicie:

1. W roku 1858 zobowiązały się do daniny tylko te numera [sic] domów, do których należało 19 morgów lub 9 morgów ziemi. Innych mniejszych nie zaliczono do daniny. Tymczasem nastąpiła parcelacja okolicznych obszarów dworskich i parafianie prawie wszyscy nakupili drugie tyle gruntu ile mieli, tak, że są tu gospodarstwa liczne o 30, 40, 60 morgach ziemi, które jednak z nowo nabytego gruntu zboża nie dają, co się sprzeciwia duchowi zobowiązania z r. 1858, gdyż w owym roku nikt więcej z parafian ponad 19 morgów nie posiadał, gdyż między kolonistów rozdzielono kompleksy po 19 morgów mające. 
2. Wskutek parcelacji powstały w powyższych gminach nowe gospodarstwa a nawet gminy, jak Kontrowers i Wola Obłaźnicka, obejmujące nierzadko po 20 morgów, które zboża nie dają, bo nie istniały w roku 1858. W Machlińcu powstało w ten sposób 26 nowych gospodarstw, które zboża nie dają, bo nie ma ich w owych 50 numerach z roku 1858-go.

3. Niektóre znowu z owych numerów z r. 1858 do tego czasu znikły, gdyż grunt rozdzielili rodzice powoli między dzieci i z gruntu rozdzielonego daniny nikt nie uiszcza, bo z owych 19-tu morgów powstały cząstki o 2, 4 i 6 morgach, które do daniny nie są obowiązane.

Rozważywszy powyższe 3 ujemne strony, które daninę zbożową poważnie uszczuplają $\mathrm{i}$ w razie ponownego nieuregulowania uszczuplać będą $\mathrm{w}$ dalszym ciągu, tak, że po pewnych latach nie będzie miał już kto daniny zbożowej składać, przeszedłem do przekonania, że obecnie obowiązek daniny zbożowej trzeba oprzeć na nowej podstawie, odpowiadającej liczbie i stosunkom majątkowym parafian, gdyż dawny wymiar daniny grozi jej coraz większym uszczupleniem, a potem nawet zupełnym jej wygaśnięciem. Sami parafianie nawet prosili mnie, by tą rzecz na nowo uregulować, gdyż obecnie danina jednych krzywdzi po prostu a drugich najniesłuszniej oszczędza, i to przeważnie bogatych, którzy dają tylko tyle, ile i biedniejsi.

W celu zasięgnięcia opinii urzędowej moich parafian zwołałem w tym celu przed 2 jeszcze miesiącami Komitet kościelny braci kościelnych i kilku najpoważniejszych gospodarzy i na tym zebraniu uchwalono:

1. Ze względu na to, że obecny wymiar daniny zbożowej dla księdza ekspozyta dokonany jeszcze w r. 1858 dziś nie odpowiada już stosunkom majątkowym mieszkańców parafii machlinieckiej, gdyż bogacze dają za mało a biedni za dużo, a nowo osiedleni parafianie nie dają zboża wcale, zebrani wyrażają przekonanie i życzenie, by zsyp zboża dla księdza uregulować na nowo w ten sposób, by każdy parafianin do Machlińca należący składał tyle zboża, ile wynosi jego posiadłość w gruncie, to jest, by każdy składał od 1 morga gruntu pewną ilość kilogramów zboża. Taki wymiar procentowy nikogo nie skrzywdzi i każdego zadowoli.

2. Upoważnia się ks. Krzystyniaka obecnego ekspozyta rz[ymsko]kat[olickiego] w Machlińcu, by ten wszczął kroki u władzy duchownej i państwowej, celem anulowania wymiaru daniny w sposób i ilości określonych w r. 1858, a zawarcia nowej umowy co do wymiaru daniny zbożowej dla ekspozyta w Machlińcu na tej podstawie, by każdy parafianin grunt posiadający składał od 1 morga posiadanego, pewną później przy samej umowie ustalić się mającą ilość zboża.

Od siebie dodaję, że nowe uregulowanie daniny, w powyż przytoczony sposób i samą daninę znacznie powiększy a praktycznie ogromnie ułatwi, gdyż każdy z góry będzie wiedzieć ile zboża ma dać. Biedny da mniej, bogaty więcej, zależy od ilości ziemi, a którzy nie dawali, obecnie dać muszą i nie będzie w tym względzie żadnego ograniczenia ani co do ilości dających numerów, ani co do ilości kg zboża, gdyż każdy tyle musi dać, taką ilość, ile mieć będzie morgów gruntu.

Upraszam zatem Najprzewielebniejszą Kurię o łaskawe pozwolenie zawarcia umowy z parafianami na podstawie powyższych wniosków, a ja już sprawy tak dopilnuję, by tą daninę zbożową uregulować jak najpomyślniej i najkorzystniej 
dla księży ekspozytów w Machlińcu pracować mających. Obowiązek dostarczania 80 fur w drzewo zostanie ten sam, jak dawniej.

\section{Budowa kaplicy dla Polaków w Nowym Siole}

W mojej parafii jest duża wieś Nowe Sioło, gdzie w roku 1912 z inicjatywy księdza Kleina-Szafryńskiego zaczęto budować kaplicę dla parafian Polaków z Nowego Sioła i Woli Obłaźnickiej. Jak już na początku wspomniałem Niemcy z Nowego Sioła i z innych gmin parafialnych ani ,palcem nie kiwnęli” by przy tej budowie pomóc, gdyż to kaplica für Polaken ${ }^{79}$. Żaden Niemiec dosłownie nie przywiózł za darmo ani jednego ziarnka piasku, ani jednej cegły, nie dał ani jednego halerza przedwojennego.

Ponieważ Polacy w Nowym Siole to przeważnie sami biedacy, więc co mogli to na kaplicę dali, resztę dali dobrzy ludzie i w ten sposób z datków obcych wzniesiono fundamenty i mury kaplicy aż do więźby dachowej; wojna przeszkodziła dalszej budowie i dokończeniu kaplicy. Materiał drzewny na dach i podłogi zabrali Prusacy i Austriacy na naprawę mostów na drogę do Żydaczowa ${ }^{80}$; zostały tylko gotowe już drzwi i okna, z belek i desek ani śladu. Zrąb kaplicy gotowy, ale bez sufitu i dachu stał i stoi do dziś narażony na wilgoć i deszcze; nie mogą one jednak murom dużo szkodzić, bo mury wzniesiono z bloków cementowych.

Naprawdę, że mi się serce krwawi, ile razy jadę koło tej niewykończonej kaplicy, która jest obecnie przedmiotem śmiechu Niemców, mówiących, że „Polakom to chyba już sam Pan Bóg kaplicę wykończy, gdy im marki z nieba spuści”. Gdym tu tylko przybył, by Polaków zachęcić do budowy, zacząłem w kaplicy odprawiać pod gołym niebem co niedzielę nieszpory, po nieszporach w Machlińcu; odnowiłem Komitet budowy kaplicy, zobowiązałem Polaków do pewnej daniny pieniężnej na rzecz budowy kaplicy, lecz że to biedacy, uzbierało się zaledwie około 50 tysięcy marek, a tu dokończenie, licząc samą robociznę, tylko wyniesie blisko $1 / 2$ miliona marek. Wobec tego liczyć trzeba tylko na ofiarną obcą pomoc. Przy dokończeniu kaplicy liczę najpierw na łaskawą pomoc Najprzewielebniejszej Kurii Metropolitalnej, która przed wojną fundusz budowy łaskawie poważnie zasilała; dalej liczę na pomoc Ekspozytury Odbudowy w Żydaczowie, która musi nam zwrócić rozkradziony przez wojsko materiał; dalej na pomoc Pana hr. Dzieduszyckiego Konstantego ${ }^{81}$ z Izydorówki, na sąsiednie parafie i braci kapłanów, którzy swych parafian zachęcą pewnie na mą prośbę do dania nam choć niewielkiej sumy i użyczą nam pomocy przy zwiezieniu materiału drzewnego; robociznę musimy sami opłacać, a ponieważ jest drogą, wyniesie stosunkowo wielką sumę. Lecz Łaskawy Bóg pewnie nam pomocy nie odmówi i kaplicę tego roku już dachem przynajmniej nakryjemy. Aby zaś Polaków, póki nie dokończymy kaplicy, bez opieki duchownej nie zostawiać, będę jeździł do kaplicy co 2 niedzielę popołudniu do nich na nieszpory, po nieszporach w Machlińcu, za każdym ra-

\footnotetext{
${ }^{79}$ Niem.: dla Polaczków [pogardliwie].

${ }^{80}$ Żydaczów - miasto pow., woj. stanisławowskie.

${ }^{81}$ Patrz przypis nr 62.
} 
zem powiem kazanie. W inną zaś niedzielę muszę jeździć nieszporami do kaplicy w Krechówce, o czym niżej.

Prośba: Przy tej sposobności ośmielam się prosić Najprzewielebniejszego Arcypasterza by tak, jak i przed wojną, budową owej kaplicy w Nowym Siole najłaskawiej zainteresować się raczył i proszę również imieniem wszystkich tutejszych Polaków i Komitetu budowy Najprzewielebniejszą Kurię o łaskawe choćby niewielkie zasilenie funduszu dokończenia kaplicy, co moim polskim parafianom będzie materialną i duchową zachętą w pracy koło budowy owej kaplicy.

W celu zbierania datków i ofiar zamierzam wydać odezwę do społeczeństwa polskiego we wschodniej Małopolsce z prośbą o materialne poparcie, a tymczasem sam wysłałem już kilka próśb do rozmaitych wpływowych i zamożnych osób z petycją o ofiary na rzecz budowy.

Drzewo na sufit i dachowanie mam przyobiecane $u$ Pana hr. Dzieduszyckiego Konstantego z Izydorówki i u Pana Barona Heitla ${ }^{82}$ z Sokołowa.

Swego czasu wysłał do Najprzewielebniejszej Kurii Metropolitalnej ksiądz Kielar $^{83}$, dawny ekspozyt w Antoniówce ${ }^{84}$ a obecny proboszcz w Markowej ${ }^{85}$, księgę Komitetu budowy kaplicy w Nowym Siole, z wykazem dochodów i rozchodów i inne akta budowy się tyczące oraz 500 koron z pozostałości kasowej Komitetu budowy. Proszę zatem o najłaskawsze i szybkie przysłanie pod mym adresem owej książki i sumy pieniężnej, gdyż owa księga jest mi obecnie bardzo potrzebną i użyteczną ${ }^{86}$

Przy tej sposobności proszę również Najprzewielebniejszą Kurię Metropolitalną o łaskawe wskazanie mi jakiejś dobroczynnej instytucji, gdzie bym mógł już obecnie zamówić dla kaplicy paramenta mszalne i kościelne po tańszej cenie, lub może za darmo. ${ }^{87}$

${ }^{82}$ Nie zdołano ustalić bliższych danych biograficznych.

${ }^{83}$ Jan Kielar (1877-1960) - święcenia kapłańskie w 1902 r. we Lwowie, wikariusz par. Kozłów 1902-1903, wikariusz par. Skałat 1903-1904, wikariusz par. Monasterzyska 1904-1905, wikariusz par. Czerwonogród 1905-1907, administrator tamże 1907-1908, wikariusz-ekspozyt par. Darachów 1908-1912, wikariusz-ekspozyt par. Bryńce Zagórne 1912-1913, wikariusz-ekspozyt par. Antoniówka 1913-1914, kapelan wojskowy 1914-1918, administrator par. Markowa 1918-1924, dwukrotnie aresztowany i więziony przez Ukraińców w 1919 r., proboszcz par. Kowalówka 19241934, proboszcz par. Mosty Wielkie 1934-1945. W ramach ekspatriacji wyjechał na Zachód - osiadł w Chlewiskach (archidiec. gnieźnieńska). Zmarł w Jaworze. Kościół rzymskokatolicki i Polacy w Małopolsce Wschodniej podczas wojny ukraińsko-polskiej 1918-1919. Źródła, t. 1, oprac. J. Wołczański, Lwów-Kraków 2012, s. 551.

${ }^{84}$ Antoniówka - wieś w pow. Żydaczów, woj. stanisławowskie.

${ }^{85}$ Markowa - wieś w gm. Zawałów, pow. Podhajce, woj. tarnopolskie.

${ }^{86}$ Obok akapitu, na marginesie z lewej strony, adnotacja ołówkiem ręką abp. Józefa Bilczewskiego: ,wysłać”.

${ }^{87}$ Obok akapitu, na marginesie z lewej strony, adnotacja ołówkiem ręką abp. Józefa Bilczewskiego: „dam”. 
W tym względzie liczę również na okoliczne kościoły, a szczególnie na Przewielebnego Księdza Prałata Trzopińskiego ${ }^{88}$ z Kochawiny, który jak zawsze innym, tak i nam swej pomocy i rady opartej na doświadczeniu nie poskąpi.

O owe nadesłanie księgi Komitetu Budowy jeszcze raz najpokorniej upraszam, gdyż jest nam ona niezbędnie obecnie potrzebną do rozpoczęcia dalszej pracy $\mathrm{w}$ budowie ${ }^{89}$.

\section{Sprawa wsi Krechówki}

\section{a) wieś Krechówka}

Krechówka wieś, kolonia góralska, powstała mniej więcej przed laty 20 -stu, kiedy Ksiądz Prałat Trzopiński sprowadzał swych rodaków-górali ${ }^{90}$ do swej parafii na dobra przez siebie rozparcelowane, po poprzednich obywatelach nabyte. Krechówka się rozszerzała i dziś liczy numerów domu 30 (trzydzieści) i mieszkańców 203 (dwieście trzech). W roku 1920 i [19]21-szym zaczęli ci górale emigrować do Poznańskiego; wyemigrowało rodzin 5; 4 rodziny sprzedały niestety domostwa Rusinom, jedna Niemcowi. Dziś jest w Krechówce: 26 numerów polskich, 1 niemiecki, 3 ruskie i jeden ruski w budowie. Polaków-górali jest obecnie dusz 180, reszta 23 [to] Rusini i Niemcy, którzy jednak w tej bądź co bądź czysto polskiej wsi swej narodowości nie okazują, po polsku mówią i do szkoły polskiej w Krechówce dzieci posyłają. Umyślnie owe dane co do numerów i ilości mieszkańców podaję, gdyż o ile wiem, otrzymała Najprzewielebniejsza Kuria skądinąd wiadomości nieścisłe i nie zupełne ${ }^{91}$; te wiadomości właśnie uzupełniam, na podstawie osobistego u wójta w Krechówce obliczenia.

b) Kościół (kaplica) w Krechówce

Za inicjatywą byłego ekspozyta w Machlińcu ks. Kleina-Szafryńskiego zaczęli górale-koloniści budować w r. 1912 w Krechówce drewnianą kaplicę. Drzewo dała hr. Dzieduszycka ${ }^{92}$ z Izydorówki, miejsce pod kaplicę jeden gospodarz i kaplicę przed wojną wybudowano, ładną dość, z wieżą nawet, jednakże wnętrza wskutek wojny nie zdołano dokończyć. Zewnętrznie więc kaplica jest zupełnie gotową, wewnątrz jednak brakuje posadzki, ołtarza itd. Stan ten trwa już całą wojnę aż do dziś; z kaplicy taki tylko użytek, że w maju odprawiają się tam nieszpory majowe, naturalnie bez księdza. W Krechówce sprawa dokończenia kaplicy

${ }^{88}$ Jan Trzopiński (1855-1931) - święcenia kapłańskie w 1883 r. we Lwowie, wikariusz par. Kamionka Strumiłłowa 1883-1886, administrator par. Kochawina 1886-1898, proboszcz tamże 1898-1931; organizator życia parafialnego, budowniczy nowego kościoła, inicjator koronacji obrazu Matki Bożej Kochawińskiej w 1912 r., animator akcji katolicko-społecznej, prałat papieski. Kościół rzymskokatolicki i Polacy, s. 177.

${ }^{89}$ Obok akapitu, na marginesie z lewej strony, adnotacja ołówkiem ręką abp. Józefa Bilczewskiego: ,zaraz”.

${ }^{90}$ Ks. Trzopiński urodził się i wychowywał w Sidzinie koło Jordanowa, obecnie pow. Sucha Beskidzka, woj. małopolskie.

${ }^{91}$ Nie zdołano ustalić na jakie informacje powołuje się ks. Krzystyniak.

${ }^{92}$ Najprawdopodobniej mowa tutaj o żonie Konstantego hr. Dzieduszyckiego - Walerii z Capińskich Dzieduszyckiej. 
przedstawia się dość łatwo, bo na najkonieczniejsze wykończenie wewnętrzne dużo wkładu już nie potrzeba, a górale dosyć bogaci mogą sami prawie wydatki pokryć. Sprawa dokończenia kaplicy ugrzęzła raczej na tym, że górali, wojną i stosunkami tutejszymi do budowy zniechęconych, nie miał kto pobudzić i do ukończenia zachęcić. Zdając sobie z tego sprawę, wprosiłem się im najpierw z nauką religii do ich szkoły, a zwiedziwszy kościółek i dowiedziawszy się o wszystkim, zebrałem wszystkich przed 2 tygodniami do kaplicy i przy Bożej pomocy tak im sprawę budowy przedstawiłem, iż mi najsolenniej przyrzekli, że najpóźniej w lecie kaplicę wykończą. Tak jak w Nowym Siole, tak i w Krechówce, objąłem przewodnictwo Komitetu budowy by czuli nad sobą kogoś, co ich będzie doglądał i na ich postęp w pracy patrzył.

W celu wydobycia funduszu na budowę dalszą, nowo obrany komitet uchwalił:

1. ściągnąć od każdego mieszkańca Krechówki pewną ilość zboża, odpowiadającą posiadanej ilości morgów gruntu oraz

2. ściągnąć również od każdego mieszkańca, zależnie od ilości morgów gruntu, pewną sumę pieniężną, na dokończenie kaplicy.

$\mathrm{Na}$ zebraniu tym napiętnowałem tych, którzy obcym grunt swój sprzedali i nakazałem im, by jeśli już ktoś koniecznie grunt sprzedać musi, by sprowadził na swe miejsce swego rodaka z gór i jemu pole sprzedał. Posłuch między nimi znalazłem, gdyż to są koloniści, z tego samego górskiego powiatu, co i ja ${ }^{93}$. Kaplica w Krechówce musi być jak najprędzej wykończoną, gdyż bez tej kaplicy górale w Krechówce się nie utrzymają, mając z jednej strony niemiecki kościół w Machlińcu, a z drugiej swój kościół parafialny w Sokołowie, 9 k[i]1[o]m[etrów] od Krechówki oddalony, do którego i tak nie chodzą ani w lecie nawet. I tej sprawie więcej poniżej.

c) Jak się powinno dokonać przyłączenie wsi Krechówki do parafii Machliniec i wydzielenie jej konieczne z parafii Sokołów?

Nad całym nonsensem należenia wsi Krechówki do parafii Sokołów, gdzie z Krechówki do kościoła parafialnego w Sokołowie jest najbliższą drogą 9 k[i]l[o] $\mathrm{m}$ [etrów] nie trzeba się rozwodzić. Nonsens ten bije jasno w oczy, gdy się przypomni, że kościół w Machlińcu jest odległy od Krechówki 11/2 k[i][[o]m[etra]. Krechówka jednak, mimo to, na papierze przynajmniej do Sokołowa należy, bo Krechowianie nawet latem do Sokołowa nie chodzą, i mimo niemieckiego nabożeństwa do kościoła w Machlińcu uczęszczają. Nonsens ten niestety jest jednak stanem prawnym, i z tym trzeba się liczyć, póki on będzie istniał.

Czemu Krechówka do Machlińca nie należy? Odpowiedź prosta - bo to się Niemcom nie podobało i oni tego nie chcieli, a że tego nie chcieli Niemcy w państwie austriackim, więc Krechówka nie została do Machlińca przyłączoną. Delegacje, deputacje, protesty niemieckie, zrobiły swoje; Niemcy jak zawsze zwyciężyli. A ponieważ Ksiądz Proboszcz z Sokołowa jest wskutek słabości do

\footnotetext{
${ }^{93}$ Ks. Władysław Krzystyniak pochodził z Nowego Targu.
} 
pracy poza Sokołowem niezdolny ${ }^{94}$, powstały więc w tej Krechówce, polskiej wsi mającej za sąsiada księdza Polaka zawsze Machlińcu i swego proboszcza w Sokołowie takie o pomstę do Boga wołające horrenda, że od lat 20-stu, odkąd istnieje Krechówka, nie było do roku 1922-go ani razu żadnego księdza na jednej choćby godzinie religii, pierwszą miałem za 20 lat ja przed 4 tygodniami!

Dzieci polskie wyrastały jak chwasty na nieużyźnionym polu, nie chodziły do spowiedzi aż dopiero w starszych latach. Ogólnie mówiąc, polskie dzieci i Polacy-koloniści tracili swe dusze dla wiary i Boga, lecz za to Niemcy byli przez wszystkich zadowoleni, nie groziło im już ,spolszczenie” przez przyłączenie Krechówki, a z nią tak dla germańskiego szowinizmu niebezpiecznych 150 polskich górali. Taką jest historia tej biednej Krechówki w polskiej diecezji obsadzonej polskimi kapłanami. Naprawdę, że ręka drży przy opisywaniu tej niedoli polskich górali i brak dość dosadnych słów, by uwypuklić i oświetlić tą jakąś dziwną ustępliwość przed garstką Niemców w sprawie przyłączenia tej Krechówki do Machlińca. Gdzież zasada audiatur et altera pars ${ }^{95}$. Tylko germanicae pars ${ }^{96}$ miała posłuch, polonae ${ }^{97}$ zaś - o jej zdanie się nie pytano i z nim się nie liczono. Skutki tego jakie? Dziś je już widać, bo ich na własnej skórze już odczułem. Niemcy nabrali przekonania, że wszystko co im niewygodne mogą z drogi usunąć i ich bezczelność i buta wzrosły wskutek tego do niemożliwości, a polscy górale z Krechówki, nie mogąc wśród takich stosunków wyżyć, zaczynali już przed wojną z Krechówki się wynosić, a dziś to już $1 / 3$ część chce swe grunta posprzedawać i wyemigrować z powrotem na zachód. Niemcy zostaną a Polacy wyemigrują zaiste bardzo a bardzo dla Chrystusa, Kościoła i narodu pomyślne wyniki....

Jakżesz więc tą Krechówkę dla wiary i narodu uratować?

Na podstawie bardzo głębokiego, dzięki Bogu, wglądnięcia w stosunki i ludzi mojej parafii, muszę powiedzieć, że Niemcy obecnie nie zgodzą się bezwarunkowo na takie włączenie Krechówki do Machlińca, by wskutek tego włączenia mogło ucierpieć niemieckie nabożeństwo w kościele w Machlińcu. Im nie chodzi o samo przyłączenie Krechówki, oni obawiają się tego, że Krechowianie jako parafianie machlinieccy zażądają polskiego kazania, śpiewu itd., a oni do tego absolutnie nie chcą dopuścić. Krechowianów obecnie nikt z kościoła nie wyrzuca, ale muszą mit Geduld ${ }^{98}$ słuchać niemieckiego kazania itd.

Po głębokim namyśle, zdaję sobie sprawę z powyższego nastroju u Niemców, obecnych stosunków i okoliczności lokalnej natury, przyszedłem do przekonania, że Krechówkę można włączyć do parafii Machliniec jedynie tylko i tylko w ten sposób, jak następuje:

${ }^{94}$ Obowiązki proboszcza pełnił ks. Andrzej Treszczyński (1848-1932) - święcenia kapłańskie w 1874 r. we Lwowie, proboszcz par. Sokołów w latach 1884-1932. Schematismus [...] 1874-1933, passim.

${ }^{95}$ Łac.: należy wysłuchać i drugiej strony.

${ }^{96}$ Łac.: niemiecka strona.

${ }^{97}$ Łac.: polska [strona].

${ }^{98}$ Niem.: cierpliwie. 
Obszar wsi Krechówki wraz z jej mieszkańcami rzymskokatolickimi zostaje wyłączony z parafii rz[ymsko]kat[olickiej] Sokołów a przydzielony i wcielony do parafii rz[ymsko]kat[olickiej] Machliniec pod 2 warunkami:

1. Nowi parafianie z Krechówki przyjmują na siebie obowiązek uiszczania ciężarów w stosunku do swej liczby na rzecz kościoła i księdza ekspozyta w Machlińcu.

2. Nabożeństwo w kościele w Machlińcu zostaje nadal niemieckie, ale za to ks. ekspozyt obowiązany na zawsze będzie, przynajmniej co drugą niedzielę odprawiać w kościółku na Krechówce Mszę św. czytaną o godz. 9-tej rano i wygłosić po tej Mszy św. zawsze polskie kazanie.

W każdą zaś 4 niedzielę w miesiącu obowiązany będzie ks. ekspozyt z Machlińca do odprawiania w powyższym kościółku sumy z kazaniem i wyspowiadania $\mathrm{w}$ tą niedzielę zgłaszających się penitentów, do czego $\mathrm{w}$ inne niedziele brak mu będzie czasu.

3. Zważywszy, że wieś Krechówka ma swój własny cmentarz rz[ymsko] kat[olicki], umarłych grzebać się będzie na miejscowym cmentarzu a potrzebnych do pogrzebu paramentów i rekwizytów będzie dostarczał kościół w Krechówce.

Jakie są ogólne zasady przyłączenia właściwego Krechówki do Machlińca? Przyłączenie to musi koniecznie nastąpić w jak najbliższym czasie po ukończeniu kaplicy w Krechówce i na takie jedynie przyłączenie Niemcy się zgodzą. O innym sposobie nie można nawet myśleć ${ }^{99}$.

Przyłączenie to jest konieczne ze względów religijnych, gdyż Krechówka oddalona od swego kościoła, znajduje się w zupełnym religijnym zaniedbaniu co tylko przyłączenie naprawić może.

Przyłączenie to już faktycznie już [sic!] zwyczajowo nastąpiło, bo mieszkańcy Krechówki do kościoła w Sokołowie wcale nie chodzą, tylko do Machlińca, tu chrzczą dzieci i do pogrzebów wzywają, jak i do chorych stale, tylko księdza z Machlińca.

Potrzeba przyłączenia Krechówki jest tak nagląca i ważna, iż nie można dość silnie tej potrzeby wykazać. Dziś Krechowianie już mówią, że gdy to przyłączenie nie nastąpi, oni posprzedawają [sic] gospodarstwa swe Rusinom i wszyscy wyemigrują, bo Polacy z zachodu nie chcą od nich gruntu wykupić, z powodu tego właśnie, że Krechówka pozbawioną jest opieki duchownej, gdyż do Sokołowa za daleko, a w kościele w Machlińcu, jak życie długie, nie można słyszeć polskiego słowa. Jeśli się więc Krechówki do Machlińca nie przyłączy i to jak najwcześniej, grozi nam utrata 180 Polaków ze wschodniej Małopolski, do czego przecież nikt dopuścić pewnie nie chce i nie może.

Pewnie, że Niemcy z Machlińca i takiego im niegroźnego przyłączenia z warunkami się obawiają i tego sobie nie życzą, lecz jak dostaną zapewnienie, że w Machlińcu przez to żadnych zmian w nabożeństwie językowych nie będzie, to przy użyciu choć trochu [sic] pewnej presji ze strony władzy duchownej na to się

${ }^{99}$ Obok akapitu, na marginesie z lewej strony, adnotacja ołówkiem ręką abp. Józefa Bilczewskiego: ,zrobić”. 
zgodzą; a tak i Niemcy będą zadowoleni, a Krechówka przyłączona i uratowana dla wiary i Ojczyzny.

Ewentualny i przypuszczam spodziewany w tej sprawie sprzeciw Księdza Proboszcza ze Sokołowa nie powinien znaleźć najmniejszego respektu, gdyż wobec sprawy tak ważnej zniknąć winny wszelkie poboczne i prywatne względy, gdyż materialnej korzyści z posiadania Krechówki w parafii tak dla Sokołowa, jak i dla Machlińca wcale pomyśle nie są.

Najprzewielebniejsza Kuria Metropolitalna raczy łaskawie sprawę Krechówki rozpatrzeć i podpisanemu przysłać najłaskawsze wskazówki by jak najwłaściwiej przyłączenia owego dokonać, $\mathrm{w}$ formie przeze mnie najpokorniej proponowanej. Gdy się sprawa bowiem odwlecze, jak dotychczas, to za kilka lat, a nawet wcześniej, Krechówka będzie ruska, a kaplica siłą rzeczy obrócona na cerkiew dla Rusinów krechowskich. Sytuację uratuje tylko przyłączenie, gdyż górale, mając swą kaplicę i nabożeństwo, Krechówki nie opuszczą.

Tymczasem zaś, póki przyłączenie nie nastąpi, upraszam najpokorniej Najprzewielebniejszą Kurię o łaskawe wydanie mi pozwolenia na:

1. Chrzest dzieci z Krechówki w kościele w Machlińcu.

2. Odprawianie pogrzebów w Krechówce, gdyż Ksiądz Proboszcz grzebać nie może z powodu osłabienia i dalekiej drogi.

3. Na odprawianie co drugą niedzielę nieszporów w Krechówce, póki nie będzie można odprawić Mszy św.

4. Pozwolenie na jeżdżenie raz w tygodniu do szkoły polskiej w Krechówce.

5. Pozwolenia na prowadzenie akcji i roboty w celu dokończenia ostatecznego kościółka w Krechówce, gdyż wieś znajduje się na terytorium parafii obcej.

Zachodzi tylko kwestia, czy chrzest mam już zapisywać w księgach metrykalnych w Machlińcu, czy kartki odsyłać do Sokołowa i czy ewentualne iurae stolae (bardzo rzadkie) należeć się mają mnie, czy księdzu w Sokołowie?

O wyjaśnienie powyższego najpokorniej upraszam.

Praca duszpasterza z Machlińca, w razie przyłączenia Krechówki, wykończenia kościoła w Krechówce i Nowym Siole, przedstawiałaby się w ten sposób:

Ekspozyt z Machlińca jeździłby w każdą niedzielę i święto na przemian, raz do Krechówki, drugi raz do Nowego Sioła, ze Mszą św. rano; tam by spowiadał i odprawił krótkie kazanie, by móc wrócić na sumę do Machlińca, gdzie by była zawsze suma i nieszpory.

W czwartą zaś niedzielę każdego miesiąca odprawiłby ekspozyt Mszę św. rano w Machlińcu i w tą niedzielę jednego miesiąca do Krechówki, drugiego do Nowego Sioła jechałby ze sumą i kazaniem, by wrócić później na nieszpory do Machlińca. Co dwa tygodnie byłaby więc Msza św. w Krechówce i w Nowym Siole, a co miesiąc suma na przemian w Krechówce i w Nowym Siole, a w Machlińcu jedna niedziela bez sumy.

Ja resumując to przyłączenie $w$ tej warunkowej formie, powiedziałem góralom, że jeśli wnet kościółek skończą, to ksiądz z Machlińca postara się o to, że będą przyłączeni do Machlińca i że ksiądz co drugą niedzielę przynajmniej do nich ze Mszą św. przyjedzie i kazanie powie, co ich taką przepoiło radością, że 
w jednym dniu ci niezamożni górale 60 tysięcy [marek] od ręki na kaplicę zebrali i jęli się jak najenergiczniej do roboty.

Proszę jeszcze raz Najprzewielebniejszą Kurię o najłaskawsze zajęcie się i załatwienie sprawy przyłączenia Krechówki do Machlińca, a owo przyłączenie błogosławione mieć będzie skutki i dla wiary i dla tych wschodnich polskich drogich nam wszystkich Kresów i naszej Archidiecezji.

\section{Zakończenie}

$\mathrm{Na}$ tej najważniejszej sprawie, jaką jest przyłączenie Krechówki, kończę to sprawozdanie. Do pisania tegoż sprawozdania nakłoniła mnie chęć usłużenia przez to przede wszystkim Sprawie Bożej, Kościołowi i Ojczyźnie naszej, przynajmniej na tej małej parafii, jaką jest parafia machliniecka. Chciałem dalej należycie poinformować moje Najwyższe Władze duchowne o prawdziwym stanie rzeczy w mojej parafii, gdyż wiem, że w tym względzie było przedtem dość dużo niedokładności, przesady z jednej i [z] drugiej strony. Szczerze wyznaję, że chciałem tylko prawdę napisać i napisałem, a jeślim kogokolwiek mimo woli tu uraził, to niech mi to Bóg i oni przebaczą, bo celem moim nie była uraza, nie moja własna satysfakcja, lecz przedstawienie osób, rzeczy i okoliczności w prawdziwym świetle, by na tym tylko mogła chwała Boża więcej zyskać, by te moje słowa mogły nie tylko dziś, lecz i na przyszłość, do zorientowania się w parafii machlinieckiej, posłużyć.

Najprzewielebniejszą Kurię Metropolitalną najpokorniej zaś upraszam o najłaskawsze zainteresowanie się tym sprawozdaniem, o najłaskawszą odpowiedź na sporne i nierozwiązane przeze mnie zaś przytoczone kwestie i pytania, do której najpokorniej się zastosują.

Machliniec, dnia 21 marca $1922 \mathrm{r}$.

Ks. Krzystyniak Władysław Ekspozyt rz[ymsko]kat[olicki]

O. A. M. D. G. ${ }^{100}$

${ }^{100}$ Skrót pochodzi od łacińskiej dewizy Zakonu oo. Jezuitów: Omnes ad maiorem Dei gloriam (Wszystko na większą chwałę Bożą). 
$* * * * *$

Koncept odpowiedzi Kurii Metropolitalnej we Lwowie na sprawozdanie ks. Władysława Krzystyniaka, Lwów 14 VI 1922 r.

$[\ldots]^{\mathrm{b}}$ trudności, $[\ldots]^{101}$ konania. $[\ldots]^{102}$ widoczny powodu $[\ldots]^{103}$ upadku na $\mathrm{du}[\mathrm{chu}][\ldots]^{104}$ Pasterz $[\ldots]^{105}$ zwątpienia w pomyślny skutek dalszej pracy, czemu W[ielebność] T[woja] w powyższym piśmie kilkakrotnie wyraz dajesz.

Przeciwnie, trudności te, których przecież nie można równać z tym, co przechodzić muszą [księża] w krajach misyjnych, powinny W[ielebność] T[woją] umacniać i krzepić na duchu. ${ }^{106}$

W stosunku do parafian $[\ldots]^{107}$ Zbawicielowego, a więc nikogo nie zrazić, i ${ }^{108}$ chętnie zapom $[\ldots]^{109}[\ldots]^{110}$ Doświadczenie uczy, że prace w sposób Chrys[tusowy $[\ldots]^{111}[\ldots]^{112}$ czas prowadzone, nadzwyczajne wprost $[\ldots]^{113}$ stosunków parafialnych powoduje.

Ponieważ jak z pisma powyższego wynika, W[ielebność Twoja] [...] $]^{114}$ pracy wybrałeś, dlatego jesteśmy pewni, że $\mathrm{w} \operatorname{Kr}\left[\right.$ echówce] [... ${ }^{115}$ sobie parafian ${ }^{116}$,

${ }^{\mathrm{b}}$ Dokument sporządzony czarnym atramentem na obu stronicach pojedynczej karty czystego papieru formatu kancelarii austriackiej. Wskutek uszkodzenia dokumentu, zwłaszcza z powodu braku sporej części górnego rogu, treść w całości jest niemożliwa do odtworzenia. Na pierwszej stronie adnotacje kancelarii kurialnej: „2759/22”, „Machliniec Ekspozytura”, „16/6”; Brak fragmentu tekstu spowodowany uszkodzeniem dokumentu.

${ }^{101}$ Brak fragmentu tekstu spowodowany uszkodzeniem dokumentu.

${ }^{102} \mathrm{Jw}$.

${ }^{103} \mathrm{JW}$.

${ }^{104} \mathrm{JW}$.

${ }^{105} \mathrm{JW}$.

${ }^{106}$ Poniżej istnieje fragment, przekreślony jednak czerwoną kredką i ołówkiem, o następującej treści: „Wszak Bóg nikogo nie doświadcza nad siły; im tedy większe trudności, tym pewniejsza i bliższa pomoc i pociecha niebieska, nieraz nawet cudowna. Potrzeba tylko w tych ciężkich chwilach umieć za przykładem Zbawiciela „siebie wyniszczyć”, to znaczy zupełnie poświęcić siebie i swoje osobiste przekonania, a do pracy wziąć się na sposób Chrystusowy, który nigdy nie zawodzi, to jest pracować w najczystszej intencji, zostawiając na boku najlepsze nawet cele o ile one nie odnoszą się do chwały Bożej i zbawienia dusz ludzkich jako też w stosunku do parafian. Kierował się jedynie [...]."

${ }^{107}$ Brak fragmentu tekstu spowodowany uszkodzeniem dokumentu.

${ }^{108}$ Bezpośrednio przed tym wyrazem istniała fraza „, a natomiast być pomocnym”- przekreślona przez autora konceptu.

${ }^{109}$ Brak fragmentu tekstu spowodowany uszkodzeniem dokumentu.

${ }^{110} \mathrm{Jw}$.

${ }^{111} \mathrm{JW}$.

$112 \mathrm{Jw}$.

${ }^{113} \mathrm{JW}$.

${ }^{114} \mathrm{JW}$.

$115 \mathrm{JW}$.

${ }^{116}$ Bezpośrednio po tym wyrazie istniała fraza „rozgrzejesz” - przekreślona przez autora konceptu. 
rozpalisz ich większą $[\ldots]^{117}$ i podatnymi uczynisz do przeprowadzenia dobry[ch uczynków]. [... $]^{118}$

Co się zaś tyczy dezyderatów, w prośbie powyższej wyrażon[ych] [... $]^{119}$ cieszymy się bardzo, że budowa kaplicy w Nowym Sio[le ma się ku] końcowi i aby przyśpieszyć jej otwarcie, udzielimy W[ielebności] [wsparcia środkami], którymi dysponujemy, subwencji w kwocie $20000 \mathrm{~m}$ [are]k.

Co się zaś tyczy Krechówki, to przychylimy się do prośby W[ielebności Twojej]. Kaplica tamtejsza będzie poświęcona, wydamy zarządzenia, mocą których opiekę duchowną nad tamtejszymi parafianami oddamy ekspozyturze w Machlińcu. Z przyłączeniem jednak Krechówki do Machlińca w sposób taki, który by uzyskał także i uznanie państwowe na razie się wstrzymujemy, a to dlatego, ponieważ obecnie obowiązuje jeszcze dawna ustawa austriacka o stosunkach gmin parafialnych katolickich, a przepisy w niej zawarte, uniemożliwiają przeprowadzenie tego wyłączenia. Jest jednak nadzieja, że ustawa ta w krótkim czasie zniesioną [zostanie].

Celem zaopatrzenia tej kaplicy w przybory liturgiczne, przeznaczamy ${ }^{120}$ dla niej jeden aparat mszalny, po który W[ielebność] T[woja] zgłosi się do P.T. Ordynariusza.

Wstrzymujemy się natomiast z zatwierdzeniem zamiaru W[ielebności] Twojej, aby ekspozyt tamtejszy był obowiązany co czwartą niedzielę ${ }^{121}$ wyjeżdżać z sumą do Nowego Sioła, względnie do Krechówki, opuszczając wtedy sumę w Machlińcu. Czynimy to dlatego, ponieważ W[ielebność] T[woja] w piśmie powyższym wspominasz na jednym miejscu, że ekspozyt ma co czwartą niedzielę odprawiać sumę w Krechówce, a w drugim, że w jedną czwartą niedzielę ma odprawiać w Nowym Siole, a w drugą (a więc co ósmą) w Krechówce. Ponieważ, jak widać, sprawa ta nie jest i dla W[ielebności] Twojej dostatecznie jasna, ponieważ nadto obawiamy się, że parafianie w Machlińcu, którzy stanowią 9/10 parafian będą na to narzekać, wreszcie, ponieważ kościół w Krechówce, według sprawozdania W[ielebności] T[wojej] oddalony jest od Machlińca [za]ledwie półtora kilometra, dlatego co do tej sprawy wydamy później osobne zarządzenie po uprzednim wysłuchaniu opinii ks. dziekana ${ }^{122}$.

${ }^{117}$ Brak fragmentu tekstu spowodowany uszkodzeniem dokumentu.

$118 \mathrm{Jw}$.

$119 \mathrm{Jw}$.

${ }^{120}$ Uprzednio w tym miejscu widniało słowo „udzielimy” - przekreślone przez autora konceptu.

${ }^{121}$ Bezpośrednio po tym wyrazie istniała fraza „by miał obowiązek” - przekreślona przez autora konceptu.

${ }^{122}$ Był nim wówczas ks. Aleksander Cisło w Stryju. Poniżej dokumentu odręczna parafka bpa Bolesława Twardowskiego zatwierdzająca do wysłania treść: „Exp[editum] B[isku]p.” oraz czerwoną kredką data: „,14/6 [1]922”. 


\section{BIBLIOGRAFIA}

\section{Źródła rękopiśmienne}

Archiwum im. abp. Eugeniusza Baziaka w Krakowie

sygn. 840, Sprawozdanie ks. Władysława Krzystyniaka o stanie parafii Machliniec, 21 III $1922 \mathrm{r}$.

Archiwum Kurii Metropolitalnej w Krakowie (AKMK)

sygn. B 519, Tabela służbowa ks. Władysława Krzystyniaka, b. d.

\section{Źródła drukowane}

Bilczewski Józef, Okólnik do Duchowieństwa i Wiernych Archidiecezji lwowskiej ob. łac. z powodu wyboru Piusa XI, „Kurenda Kurii Metropolitalnej obrządku łacińskiego we Lwowie, 1922, nr 2, s. 7-8.

Eksterminacja narodu polskiego i Kościoła rzymskokatolickiego przez ukraińskich nacjonalistów w Małopolsce Wschodniej w latach 1939-1945. Materiaty źródłowe, oprac. Józef Wołczański, cz. 1, Kraków 2005; cz. 2. Kraków 2006.

Inwokacja «Królowo Korony Polskiej» w Litanii Loretańskiej, „,Kurenda Kurii Metropolitalnej obrządku łacińskiego we Lwowie, 1920, nr 3, s. 7-8.

Kościół rzymskokatolicki i Polacy w Małopolsce Wschodniej podczas wojny ukraińsko-polskiej 1918-1919. Źródta, t. 1, oprac. Józef Wołczański, Lwów-Kraków 2012, s. 551.

List pasterski biskupów polskich o matżeństwie do duchowieństwa i wiernych, 20 października $1921 \mathrm{r}$.

Ruch wszechniemiecki na Wschodzie, „Goniec Częstochowski”, 1907, nr 264, s. 1.

Schematismus [Elenchus, Catalogus] archidioecesis Leopoliensis ritus latini 1853-1939, Leopoli 1853-1939.

Schematyzm archidiecezji w Lubaczowie, Lubaczów 1981.

\section{Opracowania}

Chajko Grzegorz, Arcybiskup Bolesław Twardowski (1864-1944) metropolita lwowski obrządku łacińskiego, Rzeszów 2010.

Dzieduszycki Konstanty, w: Posłowie i senatorowie Rzeczypospolitej Polskiej 1919-1939. Stownik biograficzny, t. 1, red. Andrzej Krzysztof Kunert, Warszawa 1998, s. 451-452.

Krasny Piotr, Kościót parafialny p.w. Świętej Trójcy w Machlińcu, w: Kościoły i klasztory rzymskokatolickie dawnego województwa ruskiego, t. 9, red. Jan K. Ostrowski, Kraków 2001, s. 95-99.

Poliszczuk Wiktor, Zginęli z rąk ukraińskich, Toronto 1998.

Poliszczuk Wiktor, Posłanie do braci Polaków. Prawosławnego Ukraińca w 55-ta rocznice mordów wotyńskich, Toronto-Warszawa 1998.

Poliszczuk Wiktor, Ukraińskie ofiary OUN-UPA, Toronto 1998.

Słownik geograficzny Królestwa Polskiego i innych krajów słowiańskich, red. Filip Sulimierski, Bronisław Chlebowski, Władysław Walewski, t. 5, Warszawa 1884, s. 873.

Smólski Grzegorz, Kolonie i stosunki niemieckie w Galicji, Kraków 1910.

Szczerbiński Henryk, Deutschtumsbund zur Wahrung der Minderheitsrechte in Polen, w: Encyklopedia Historii Drugiej Rzeczypospolitej, red. zbior., Warszawa 1999, s. 75.

Torzecki Ryszard, Kwestia ukraińska w Polsce w latach 1923-1929, Kraków 1989.

Torzecki Ryszard, Polacy i Ukraincy. Sprawa ukraińska w czasie II wojny światowej na terenie II Rzeczypospolitej, Warszawa 1993. 


\section{Prasa}

Chajko Grzegorz, O Niemcach i Polakach w Matopolsce Wschodniej, „Kurier Galicyjski”, 2013, nr 11, s. 15.

\section{RELACJE NIEMIECKO-POLSKIE \\ W RZYMSKOKATOLICKIEJ PARAFII PW. ŚWIĘTEJ TRÓJCY \\ W MACHLIŃCU W ARCHIDIECEZJI LWOWSKIEJ OBRZACDU LACIŃ- SKIEGO W PRZEKAZIE KS. WLADYSEAWA KRZYSTYNIAKA Z 1922 ROKU}

\section{Streszczenie}

Historia Kresów Południowo-Wschodnich w okresie II Rzeczypospolitej wciąż pełna jest „białych plam”, które czekają na odkrycie. Dotyczy to również badań nad relacjami pomiędzy narodami zamieszkującymi te ziemie przed II wojną światową. Niniejsza publikacja szczegółowo przybliża i opisuje warunki życia Niemców i Polaków w rzymskokatolickiej parafii Machliniec koło miasta Stryja w archidiecezji lwowskiej według stanu z 1922 r., w parafii, w której zdecydowaną większość wiernych stanowiła pierwsza nacja. W artykule można zatem znaleźć szczegółowe informacje dotyczące warunków ich życia codziennego, wielopłaszczyznowych odniesień do spraw Kościoła rzymskokatolickiego, a przede wszystkim kwestii liturgii odmawianej w językach narodowych. Sporo miejsca poświęcono zwłaszcza społeczności polskiej, która w zdominowanej przez Niemców parafii posiadała ograniczone prawa i swobody. Omawiana publikacja w zasadniczej części składa się z edycji źródłowej sprawozdania przesłanego w 1922 r. do Kurii Metropolitalnej we Lwowie przez ówczesnego duszpasterza w Machlińcu ks. Władysława Krzystyniaka. Tekst dokumentu opracowano i opatrzono licznymi przypisami, a także poprzedzono wprowadzeniem redakcyjnym, który przybliża go czytelnikom. Całość uzupełnia krótki koncept odpowiedzi Kurii, skierowany do ks. Krzystyniaka, który mimo faktu, iż nie zachował się w całości, stanowi i tak ważny dowód na to, iż kwestie poruszone przez autora zostały zauważone i nie zlekceważone. Edytowany dokument ks. Krzystyniaka nie był jak dotąd publikowany.

Słowa kluczowe: relacje niemiecko-polskie; archidiecezja lwowska; ks. Władysław Krzystyniak; Machliniec, Lwów, Małopolska Wschodnia 


\title{
GERMAN-POLISH RELATIONS IN THE ROMAN CATHOLIC PARISH OF THE HOLY TRINITY IN MACHLINIEC IN THE ARCHDIOCESE OF LVIV OF THE LATIN RITE IN REV. WLADYSEAW KRZYSTYNIAK'S ACCOUNT OF 1922
}

\begin{abstract}
Summary
The history of the South-East Borderlands during the period of the Second Republic of Poland is still full of 'missing pieces', which are yet to be discovered. This also refers to research on the relations between nations living in this area before the Second World War. The following publication presents in detail the living conditions of the Germans and the Poles in the Roman Catholic parish in Machliniec near the town of Stryja in the archdiocese of Lviv in 1922, the parish where the former nation was in the majority. The article includes detailed information on their daily life, multifaceted references to the issues connected with the Roman Catholic Church, and above all the liturgy recited in national languages. There is also a good deal of information on the Polish community which had limited rights and liberties in the parish dominated by the Germans. The discussed publication consists mostly of the edition of the source account sent to the Metropolitan Curia in Lviv by the then priest in Machliniec Rev. Władysław Krzystyniak in 1922. The document was analysed and preceded by an editorial preface, which outlines the content of the text. In addition, numerous footnotes were added to it. It is also complemented by a short concept of Curia's response, addressed to Rev. Krzystyniak, which - despite the fact that it didn't survive in its entirety - is good proof that the issues raised by the author were noticed, not neglected. The edited document of Rev. Krzystyniak has not been published so far.
\end{abstract}

Keywords: German-Polish relations; the archdiocese of Lviv; chaplaincy; Rev. Władysław Krzystyniak; Machliniec; Lviv; Eastern Małopolska 